\title{
Synthesis of $\beta$-galactosylamides as ligands of the peanut lectin. Insights into the recognition process
}

\author{
María Emilia Cano ${ }^{\mathrm{a}, \mathrm{b}}$, Oscar Varela ${ }^{\mathrm{a}, \mathrm{b}}$, María Isabel García-Moreno ${ }^{\mathrm{c}}$, José Manuel García Fernández ${ }^{\mathrm{d}}$, \\ José Kovensky ${ }^{\mathrm{e}}$, María Laura Uhrig ${ }^{\mathrm{a}, \mathrm{b}, *}$ \\ ${ }^{a}$ Universidad de Buenos Aires. Facultad de Ciencias Exactas y Naturales. Departamento de Química Orgánica. Pabellón 2, Ciudad Universitaria, C1428EHA - Buenos Aires, \\ Argentina ${ }^{b}$ Consejo Nacional de Investigaciones Cientificas y Técnicas (CONICET)-UBA. Centro de Investigación en Hidratos de Carbono (CIHIDECAR). Buenos Aires, \\ Argentina \\ `Departamento de Ouímica Orgánica, Facultad de Ouímica, Universidad de Sevilla, c/ Profesor García González 1, 41012, Sevilla, Spain \\ Instituto de Investigaciones Químicas (IIQ), CSIC - Universidad de Sevilla, Avda. Américo Vespucio 49, 41092, Sevilla, Spain \\ Laboratoire de Glycochimie, des Antimicrobiens et des Agroressources (LG2A)-CNRS UMR 7378, Université de Picardie Jules Verne, 33 rue Saint Leu, 80039 Amiens Cedex, \\ France
}

\section{A R T I C L E IN F O}

Article history:

Received 29 December 2016

Received in revised form 16 March

2017

Accepted 22 March 2017

Available online $\mathrm{xxx}$

Keywords:

Peanut agglutinin

$\beta$-galactosylamides

Divalent ligands

ELLA assay

Molecular dynamics

\section{A B S T R A C T}

The synthesis of mono and divalent $\beta$-galactosylamides linked to a hydroxylated chain having a $\mathrm{C} 2$ symmetry axis derived from L-tartaric anhydride is reported. Reference compounds devoid of hydroxyl groups in the linker were also prepared from $\beta$-galactosylamine and succinic anhydride. After functionalization with an alkynyl residue, the resulting building blocks were grafted onto different azide-equipped scaffolds through the copper catalyzed azide-alkyne cycloaddition. Thus, a family of structurally related mono and divalent $\beta-N$-galactopyranosylamides was obtained and fully characterized. The binding affinities of the ligands towards the model lectin PNA were measured by the enzyme-linked lectin assay (ELLA). The $\mathrm{IC}_{50}$ values were significantly higher than that of galactose but the presence of hydroxyl groups in the aglycone chain improved lectin recognition. Docking and molecular dynamics experiments were in accordance with the hypothesis that a hydroxyl group properly disposed in the linker could mimic the Glc $\mathrm{O} 3$ in the recognition process. On the other hand, divalent presentation of the ligands led to lectin affinity enhancements.

(C) 2016 Published by Elsevier Ltd.

\section{Introduction}

A number of biological events are triggered by the recognition of a glycosidic fragment by a complementary protein, such as a carbohydrate processing enzyme, a lectin or an antibody [1]. This process is highly specific and depends strongly on the configurational pattern of the sugar ligand $[2,3]$. Legume lectins provide excellent models for the study of the recognition process. Among the lectins, the Arachis hypogaea lectin (peanut agglutinin, PNA) is a relevant one, because of its specificity for $\beta$-galactosides over other monosaccharides, showing high affinity for the disaccharides $N$-acetyllactosamine and lactose [4,5], being the highest affinity ligand for the disaccharide $\beta$-D-Galp- $(1 \rightarrow 3)$-D-GalNAc [6], known as the Thomsen-Friedenreich (TF) antigen. The PNA lectin has been extensively used in the glycobiology field on inhibition studies, including our own, of a variety of $\beta$-galactoside and $\beta$-lactoside ligands [6-11].

The recognition of carbohydrates by PNA has been the subject of varied experimental and theoretical studies. Thus, crystallographic and computational investigations revealed that the PNA-lactose com-

\footnotetext{
* Corresponding author. CIHIDECAR-CONICET, Departamento de Química Orgánica, Facultad de Ciencias Exactas y Naturales, Universidad de Buenos Aires, Pabellón 2, Ciudad Universitaria, 1428 Buenos Aires, Argentina. Email address: mluhrig@qo.fcen.uba.ar (M.L. Uhrig)
}

plex is stabilized by interaction of the Gal O3 with Asp83, Gly104 and Asn127, while the Gal O4 and O6 interact with Asp83 and Asp80, respectively. Gal O4 and Gal O5 also interact with Ser211 and the side chain of the aromatic residue Tyr 125 presents $\mathrm{CH} / \pi$ stacking interactions with the more hydrophobic $\beta$-face of the Gal ring. In addition, the Glc $\mathrm{O} 3$ exhibits hydrogen bonding with Ser211, Gly213 and Leu212, interactions that explain the lower affinity of $\beta$-galactosides when compared to lactosides $[3,6,7,10,12]$. In fact, we have previously shown that the affinity of 3-deoxylactoside ligands are c.a. 15 times lower than the corresponding lactosides, due to the lack of Glc O3, which participates in the recognition process [9]. The conformation of the Gal residue in the TF antigen is identical to that of lactose, but the orientation of the reducing end with respect to the non-reducing Gal $p$ differ in these disaccharides [6c]. However, the hydroxyl groups vicinal to the glycosidic linkages (4-OH axial in the TF antigen and 3-OH equatorial in lactose) occupy the same polar region defined by Ser211, Gly213 and Leu212. ${ }^{\text {d }}$ This brings up the question of whether the integrity of the glucose residue is required for this additional interaction, or if a hydroxyl group properly positioned in the aglycone or spacer linker could mimic this $\mathrm{OH}$. One possibility is to use a flexible glycosidic bond as connection to the hydroxylated spacer, which should be able to adopt a suitable conformation that must facilitate the interaction with the lectin. However, it has been reported that the flexibility of the aglycone may be detrimental for the 
affinity. For example, the affinity of lactitol for several human galectins drops substantially compared to that of lactose $[13,14]$. The higher flexibility of the sorbitol moiety should also impact on the hydration of this residue, an a higher interaction with the solvent would account for the lower affinity [15]. Thus, a balance in the rigidity imparted by the chemical bonds seems to be crucial for the activity. Therefore, we speculate that the rather flexible disposition of a hydroxyl group in the linker should be compensated by a fragment imparting a conformational restriction to the glycosidic bond. In this context, compounds bearing an amide function linked to the anomeric position could satisfy this requirement. The conformational restrictions imposed by the high $s p^{2}$-hybridation character of amide-type nitrogen atoms [16] and the hydrogen bonding donor and acceptor capabilities of the amide group can potentially be exploited to modulate the lectin binding properties.

So far, the rather few studies performed on mono and divalent $\mathrm{N}$-conjugates have evidenced a different behavior in their interactions with the lectin, in comparison with those of $O$ - or $S$-glycosides [7-9,17-20]. In fact, is has been shown that the type of linkage can strongly affect the mobility and orientation of the putative sugar ligands about the glycosidic linkage [21].

On the other hand, the affinity of D-galactopyranosides for the PNA lectin may be enhanced by means of their multivalent presentation onto a suitable platform. The mechanisms governing the cluster effect in the binding of both D-galactose and lactose glycotopes to PNA have been previously studied [22]. With respect to multivalency, the glycoside cluster effect clearly depends on the number of copies (valency) of the carbohydrate residues but their spatial disposition is also a determinant feature [23]. Thus, the topology of the scaffold and the flexibility of the spacer segments can play a decisive role in the recognition process [24-28].

As part of our ongoing research project on the synthesis of multivalent ligands with modified glycosidic bonds, we report here the synthesis of mono and divalent $\beta$ - $N$-galactosylamides linked through hydroxylated and non hydroxylated flexible linkers to scaffolds differing in their rigidity. Their affinities toward PNA lectin were determined by enzyme-linked lectin assay (ELLA). Structurally related mono and divalent $N$-lactosides were also tested for comparative purposes. Furthermore, initial docking studies and molecular dynamics simulations were performed in order to shed some light on the interactions involved in the carbohydrate recognition domain and to explain the differences in the affinities observed.

\section{Results and discussion}

\subsection{Synthesis}

Taking into consideration the interactions that take place in the carbohydrate recognition domain of PNA lectin with disaccharide lactose [6,7] and in an attempt to validate our hypothesis on the role of a hydroxyl group adequately placed in the proximities of the Gal residue mimicking the Glc $\mathrm{O} 3$ as discussed above, the structure $\mathbf{A}$ (Fig. 1c) was designed to be used in preliminary modelling studies. Model compound $\mathbf{A}$ arises from the retrosynthetic analysis shown in Fig. 1b, where an anomeric amide function was selected for the linkage between the Gal residue and the flexible linker. It should be noted that there is a range of methodologies to efficiently form amide or pseudoamide functionalities compatible with multiconjugation strategies. Tartaric anhydride was chosen as the source of hydroxyl groups, in a sequence that resulted compatible with previous synthetic methodologies developed in our group [7-9]. The carboxylic acid released by ring-opening of tartaric anhydride may be condensed with propargyl amine for further multivalent conjugation with azide scaffolds. The analogous compound $\mathbf{B}$ (synthesized for comparative purposes), lacking the hydroxyl groups in the linker can be obtained by a similar route from succinic anhydride. The structures $\mathbf{A}$ and $\mathbf{B}$ were employed for docking studies, taking into account that the distal triazol ring might provide extra contacts with the protein as previously shown in other systems [29].

Thus, the major conformers of $\mathbf{A}$ and $\mathbf{B}$ (obtained as explained in the Materials and methods section, Fig. S1), were docked into the binding site of peanut agglutinin using the program AUTODOCK 4.2 [30]. The best docking poses of model compounds $\mathbf{A}$ and $\mathbf{B}$ bound to PNA are shown in Fig. 2 and S2. It was observed that for both model compounds, the Gal residues are surrounded by Asp83, Gly104 and Asn127 similar to the Gal residue in the lactose-PNA complex. The position of the Tyr125 was compatible with the stabilizing $\mathrm{CH} / \pi$ stacking interactions (Fig. S2). Regarding the aglycone linker, docking experiments show a similar disposition of the tartaramidyl chain in $\mathbf{A}$, with respect to that of the succinimidyl in $\mathbf{B}$. Interestingly, as expected, one of the hydroxyl groups in $\mathbf{A}$ is located in the polar environment defined by Ser211, Leu212 and Gly213 (Fig. 2a).

The auspicious docking results prompted us to synthesize ligands containing these structural motifs, according to the retrosynthetic analysis depicted in Fig. 1b.
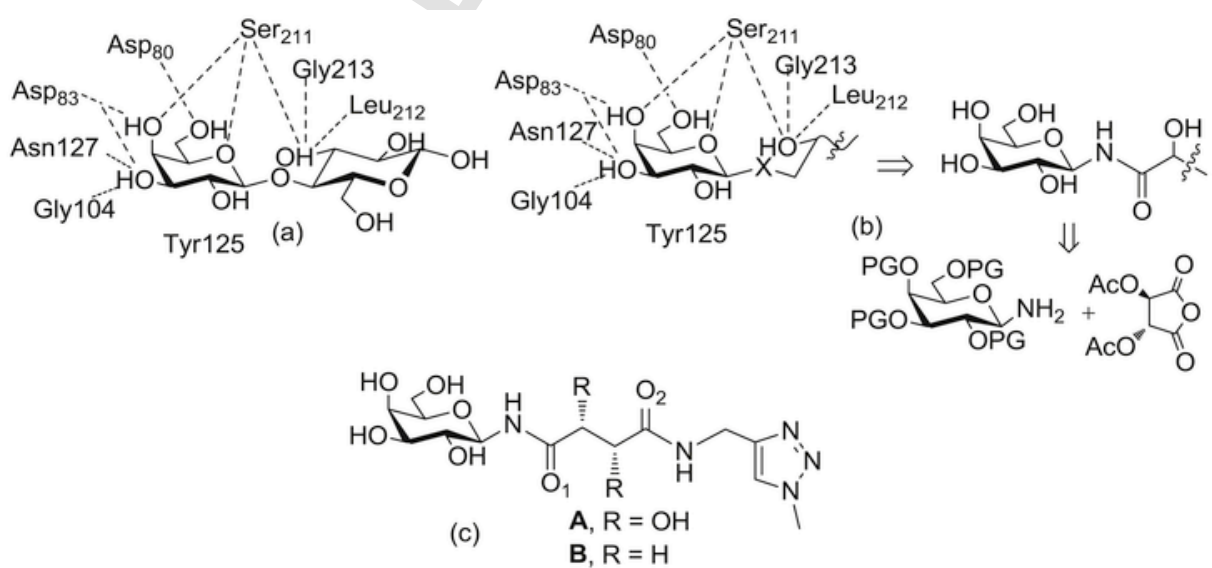

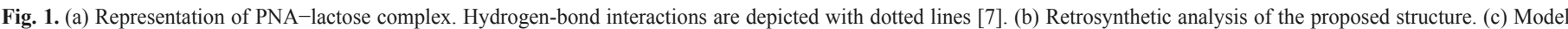
compounds $\mathbf{A}$ and $\mathbf{B}$ for docking studies. 

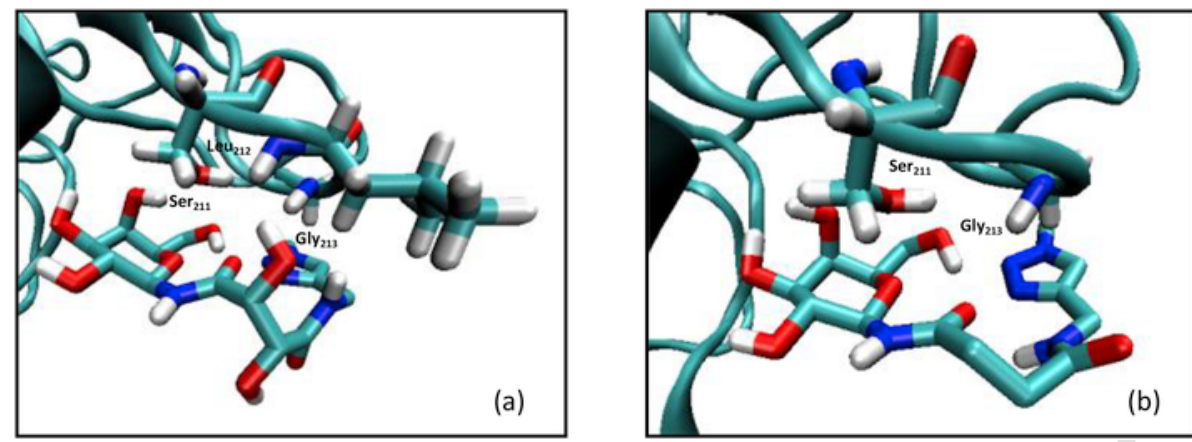

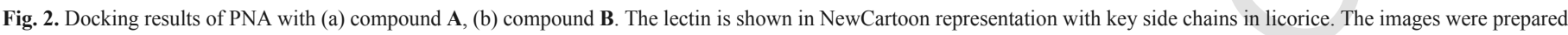
by using the VMD program.

The synthesis of the pivotal alkynyl precursor $\mathbf{5}$ was readily accomplished in two steps starting from 2,3,4,6-tetra- $O$-acetyl- $\beta$-D-galactopyranosylamine (2), which was quantitatively obtained by catalytic hydrogenation of the corresponding $\beta$-D-galactopyranosyl azide (1) [31]. As 2 was unstable in solution, it was immediately treated with di- $O$-acetyl-L-tartaric anhydride (3) to give the acid derivative 4 in $76 \%$ yield (Scheme 1).

Compound $\mathbf{4}$ was obtained as a single stereoisomer, as a result of the $C_{2}$ symmetry of the anhydride $\mathbf{3}$. Compound $\mathbf{5}$ was obtained by condensation of $\mathbf{4}$ with propargylamine, promoted by dicyclohexylcarbodiimide (DCC). The alkynyl derivative $\mathbf{5}$ was properly functionalized for the copper(I)-catalyzed azide-alkyne cycloaddition (CuAAC), a ligation reaction broadly employed in the glycosciences [24,32], which leads to the formation of 1,4-disubstituted 1,2,3-triazole rings. The succinic acid diamide analogue 6 [33], previously obtained in our laboratory, was used as control ligand.

The ${ }^{1} \mathrm{H}$ NMR spectra of $\mathbf{4 , 5}$ and $\mathbf{6}$ showed the signals of the amide protons directly linked to the sugar residue as doublets at $\delta 7.00 \mathrm{ppm}$ $(J \approx 9.2 \mathrm{~Hz})$. The anomeric proton was also coupled to the axial $\mathrm{H}-2$, and appeared as a triplet in the range $5.13-5.10 \mathrm{ppm}$, shielded by the proximity of the amide nitrogen atom.
As azide counterparts for click reactions we selected a monoazide carbohyhdrate platform as a precursor of monovalent species, and three diazide scaffolds that would give rise to divalent compounds, having similar intersaccharide distances. We and others demonstrated the suitability of sugars as scaffolds for multivalent ligands [7-9,22,34-37]. Methyl 6-azido-2,3,4-tri- $O$-acetyl- $\beta$-D-glucopyranoside (7) and 6,6'-diazido-2,3,4,2',3',4'-hexa- $O$-acetyl- $\alpha, \alpha^{\prime}$-trehalose (8), were prepared as previously described [37]. The diazides 9 or 10 derived respectively from isomannide [38] or diethylenglycol, were prepared by tosylation of the precursor diol followed by displacement of the tosyl groups with sodium azide (Fig. 3).

The typical CuAAC reaction conditions $\left(\mathrm{CuSO}_{4} /\right.$ sodium ascorbate), applied to the alkyne-armed compound $\mathbf{5}$ and azide scaffolds 7-10, led to the corresponding O-protected triazol adducts 11, 14, 17 and 21 (Fig. 4). The ${ }^{1}$ H-NMR spectrum of 11 showed the signals corresponding to the galactosyl and glucosyl groups. The diagnostic signal of the triazole proton at $\delta 7.66 \mathrm{ppm}$ and the two signals corresponding to the amide $\mathrm{N} H$ groups at $\delta 6.91 \mathrm{ppm}(\mathrm{d}, J=8.9 \mathrm{~Hz})$ and $6.83 \mathrm{ppm}(\mathrm{t}, J=5.7 \mathrm{~Hz})$ were also observed. The small $J$ value $(2.4 \mathrm{~Hz})$ of the proton signals of the linker suggested a planar zig-zag conformation for this segment. In the case of the divalent di- $\mathrm{N}$-galactopyranosyl derivatives 14,17 and 21 , the ${ }^{1} \mathrm{H}$ and ${ }^{13} \mathrm{C}$ NMR spectra
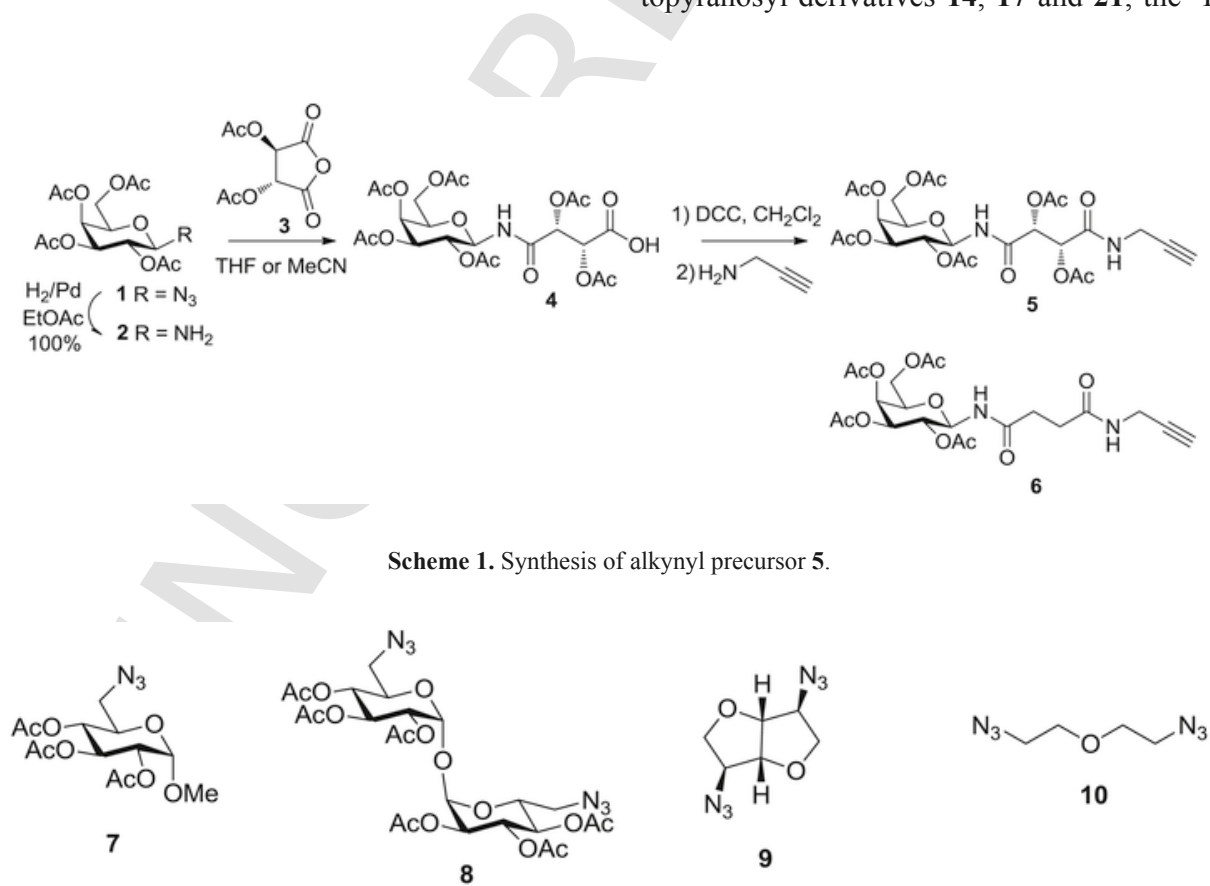

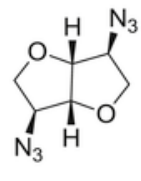<smiles></smiles>

10

Fig. 3. Azide scaffolds, precursors of monovalent and divalent ligands. 


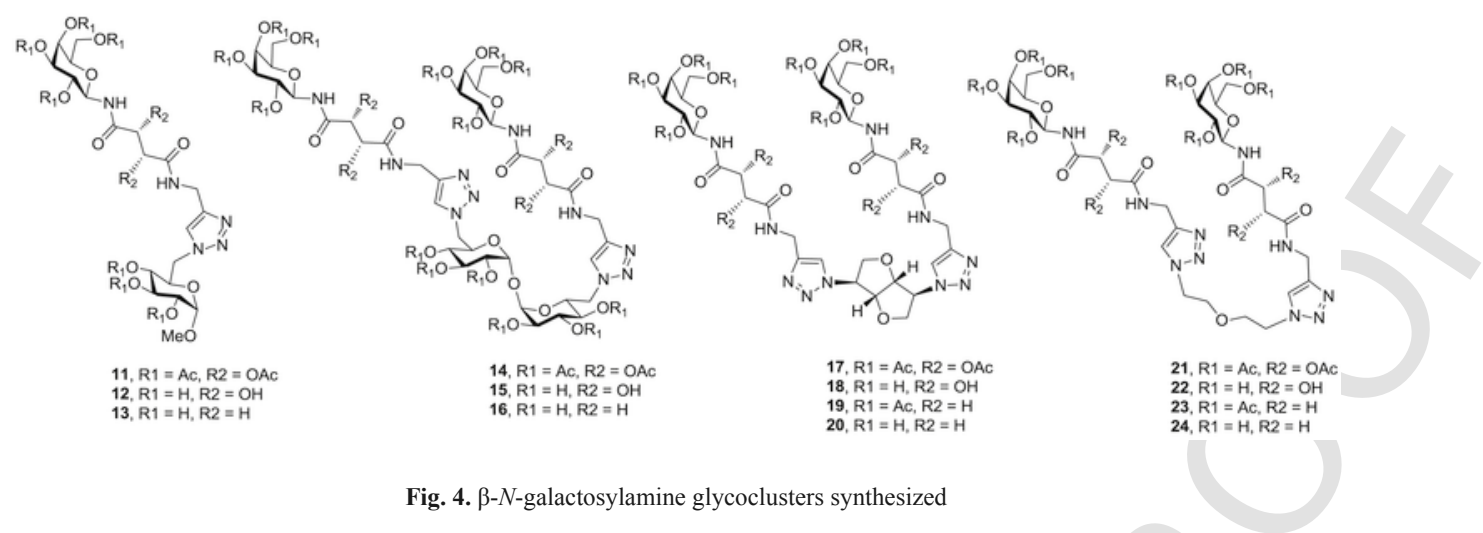

were consistent with the $C_{2}$ symmetry of the molecules. The protected products were $O$-deacetylated by treatment with triethylamine in aqueous methanol, then desalted with an exchange resin and finally purified by reverse-phase chromatography to give the fully unprotected monovalent (12) and divalent ligands (15, 18 and 22). In parallel series of reactions, the succinyl diamide monovalent (13) and divalent (16, 20 and 24) analogues were obtained. Compounds 13 and 16 had been previously reported and were synthesized again for the purpose of this study [33], whereas compounds $\mathbf{2 0}$ and $\mathbf{2 4}$ were obtained by click coupling of 9 and $\mathbf{6}(\rightarrow \mathbf{1 9})$ or $\mathbf{1 0}$ and $\mathbf{6}(\rightarrow \mathbf{2 3})$ and subsequent deacetylation.

For the free ligands 12, 15, 18, 20, 22 and 24, the signals of the anomeric protons of the N-linked $\beta \mathrm{Gal}$ residues appeared in a narrow region of the spectra (4.74-4.98 ppm) as doublets with $J \approx 9.0 \mathrm{~Hz}$, consistent with the $\beta$ anomeric configuration. The anomeric protons of the sugar scaffolds trehalose and glucose of $\mathbf{1 2}$ and $\mathbf{1 5}$ appeared at

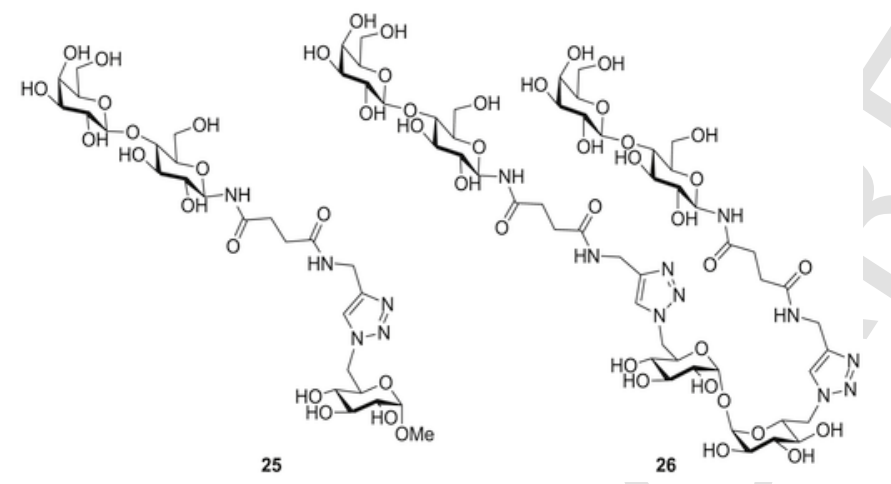

Fig. 5. Mono and divalent $N$-lactose derivatives 25 and $\mathbf{2 6 .}$

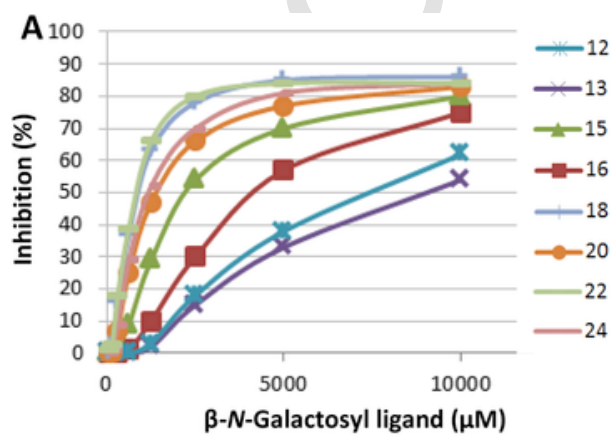

4.73 and 4.54 ppm with a $J$ value $(\approx 4.0 \mathrm{~Hz})$ characteristic of $\alpha \mathrm{Glc}$ moieties. The signals corresponding to the $\mathrm{CH}_{\mathrm{a}}-\mathrm{CH}_{\mathrm{b}}$ tether of the tartaramide unit were observed as doublets with $J_{\mathrm{Ha}, \mathrm{Hb}} \approx 1.7-2.0 \mathrm{~Hz}$. In contrast, the $\mathrm{CH}_{2}-\mathrm{CH}_{2}$ system of succinic-derived $\beta$ - $N$-galactosides showed complex multiplets with $J \approx 5.00-7.00 \mathrm{~Hz}$. The averaged $J$ values are indicative of a more flexible chain for the succinimide segment compared with that of the tartaramide analogues.

For the purpose of our structure-PNA binding affinity relationship study, we decided to test the affinity of the previously synthesized mono and divalent lactosyl derivatives 25 and 26 (Fig. 5) [33]. Compounds $\mathbf{2 5}$ and $\mathbf{2 6}$ share the same sugar-derived central scaffold as the galactosyl conjugates $\mathbf{1 3}$ and $\mathbf{1 6 .}$

\subsection{PNA binding affinity studies}

The relative binding affinities of the $N$-galactosyl $(\mathbf{1 2}, \mathbf{1 3}, \mathbf{1 5}, \mathbf{1 6}$, 18, 20, 22 and 24) and $N$-lactosyl (25 and 26) conjugates for PNA were assessed by a competitive enzyme-linked lectin assay (ELLA) [39]. This assay measures the ability of the synthetic ligands to inhibit the association of the peanut lectin (labeled with horseradish peroxidase, HRP-PNA) to a polymeric ligand that is used as a coating material at the surface of a well [40]. The $\mathrm{IC}_{50}$ values were assumed to be proportional to the corresponding binding affinities. The experiments were reproduced three times for each ligand and the individual values did not differ by more than $15 \%$. The corresponding inhibition plots and $\mathrm{IC}_{50}$ values are collected in Fig. 6 and Table 1. As compound $\mathbf{1 3}$ showed the highest value of $\mathrm{IC}_{50}$, it was taken as reference, and its relative potency was defined as 1 .

Lactose $\left(\mathrm{IC}_{50} 1.05 \mathrm{mM}\right)$ and galactose $\left(\mathrm{IC}_{50} 1.60 \mathrm{mM}\right)$ were used in the ELLA experiments as control compounds. As a general trend, compounds incorporating the L-tartaric acid diamide segment $(\mathbf{1 5}, \mathbf{1 8}$ and 22) behaved as better PNA ligands than the homologous succinic acid diamide derivatives (16, 20 and 24). For monovalent ligands (12

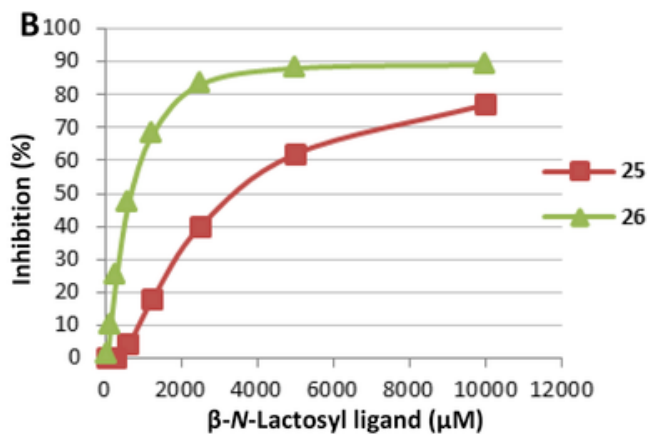


Table 1

Inhibition of lactose glycopolymer - PNA binding by mono and divalent galactosyl and lactosyl ligands determined by ELLA.

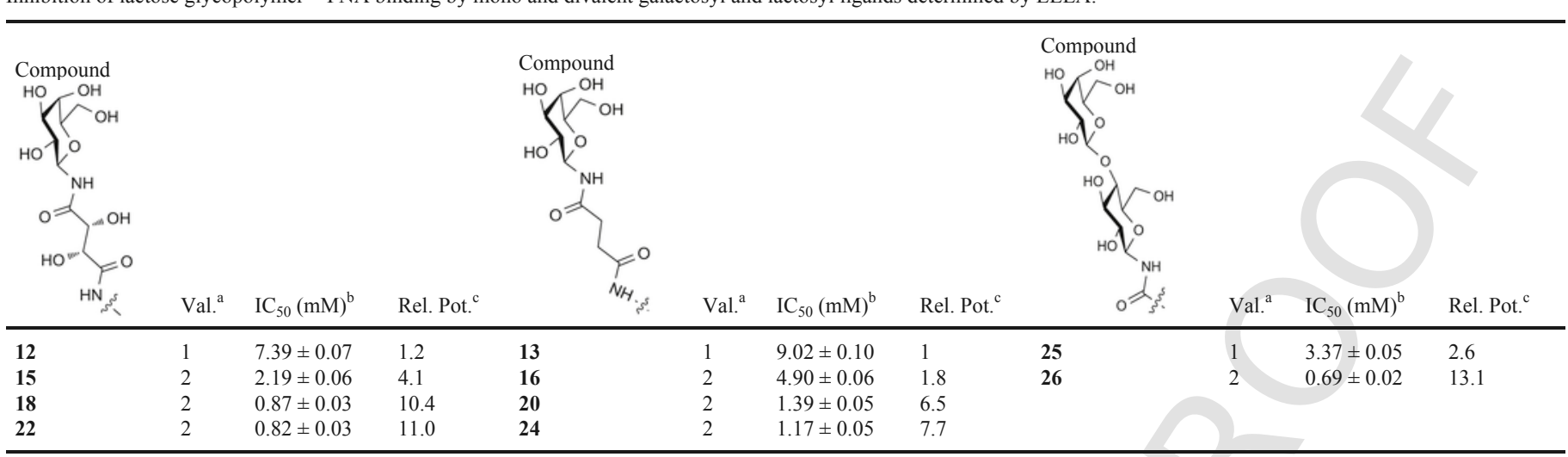

a Valency.

b $\mathrm{The} \mathrm{IC}_{50}$ values are expressed as mean values $\pm \mathrm{SD}$ obtained from at least three independent determinations.

c Relative values are compared to the monovalent compound $\mathbf{1 3 .}$

and 13), despite the geometric constraints provided by the anomeric amide linkage, which seems to perturb in some way the lectin recognition $\left(\mathrm{IC}_{50}\right.$ for galactose: $\left.1.60 \mathrm{mM}\right)$, these results are in accordance with our initial hypothesis that a properly positioned hydroxyl group in the aglycone moiety would improve the binding affinities.

On the other hand, as can be deduced from the results indicated in Table 1, PNA binding affinity increased after presenting the galactosyl motifs in divalent form. For example, the affinities of 15, 18 and $\mathbf{2 2}$ resulted higher than that of $\mathbf{1 2}$. The same was observed with the succinic acid diamide derivatives 16, 20 and 24 with respect to 13. Remarkably, the relative affinity enhancements were strongly dependent on the structure of the linker, and, again, compounds incorporating the L-tartaric acid diamide segment $(\mathbf{1 5}, \mathbf{1 8}, \mathbf{2 2})$ were better PNA ligands than the homologous succinic acid diamide derivatives $(\mathbf{1 6}, \mathbf{2 0}, \mathbf{2 4})$.

The divalent compounds also experienced a significant cluster effect when referred to the corresponding monovalent control $\mathbf{1 2}$ or 13. Within each series, the cluster effect increased on going from derivatives built on the $\alpha, \alpha^{\prime}$-trehalose scaffold $(15,16)$ to the isomannide $(\mathbf{1 8}, \mathbf{2 0})$ and diethylenglycol centered representatives (22, 24). Thus, compound $22\left(\mathrm{IC}_{50} 0.82 \mathrm{mM}\right)$, combining the tartaric acid and diethylenglycol structural elements in the connector, was 9-fold (11.0/1.2) a better ligand for PNA than the monovalent counterpart $12\left(\mathrm{IC}_{50} 7.39 \mathrm{mM}\right)$ meaning that each galactosylamide moiety is recognized with a 4.5 -fold higher efficiency. Indeed, compounds $\mathbf{1 8}$ and $\mathbf{2 2}$ presented approximately 2 -fold higher affinity than galactose itself, showing that divalent presentation can overcome the initial low affinity of a given carbohydrate motif. The preference of the lectin for lactosyl over galactosyl epitopes is observed when comparing the monoand di- $N$-galactopyranosyl conjugates $\mathbf{1 3}$ and $\mathbf{1 6}$ with the homologous mono- and di- $N$-lactosyl derivatives 25 and 26, respectively.

\subsection{Molecular dynamics simulations}

To get further insight into the dynamics and energetics of the PNA-sugar systems, we performed 100 ns long Molecular Dynamics (MD) simulations of PNA in complex with either lactose, $\mathbf{1 2}$ or 13, and analyzed the resulting protein-ligand interactions [41]. The results show that PNA interacts predominantly through Asp80, Asp83 and Ser211, with the Gal O3, Gal O4 and Gal O6, which retains this monosaccharide tightly in place. On the contrary, the Glc residue -in the case of lactose- and the linkers for $\mathbf{1 2}$ and $\mathbf{1 3}$ are much more loosely bound, and show key differences in their interactions (Fig. 7 and Fig. S3). As observed in the preliminary docking studies, the $\mathrm{OH}$ group of the linker vicinal to the galactosyl-amide in 12, shows a hydrogen bond with Leu212 amide (and with Ile101 carbonyl oxygen to a lesser extent). This interaction should be responsible for the increased affinity of the ligand $\mathbf{1 2}$ respect to $\mathbf{1 3}$, which lacks of such a hydroxyl group (Fig. S4). Hence, the absence of this interaction, results in a softer binding and higher mobility even for the bound monosaccharide (the Gal residue). The linker in $\mathbf{1 3}$ is shown to be highly flexible and stretches out to the solvent (Fig. S3).

\section{Conclusion}

In the present work, we try to establish if the whole glucose residue is required for the stabilizing interaction provided by the Glc O3 in the complex of lactose with the PNA lectin, or if a hydroxyl group properly positioned in the aglycone or spacer linker could mimic the Glc O3. We took into account that the flexibility of the hydroxylated linker should be compensated by a function imparting a conformational restriction to the glycosidic bond, as highly flexible ligands show decreased affinity by their receptor proteins in other systems. We speculate that galactosides with an amide group connecting the anomeric position and a hydroxylated chain could satisfy such requirements. Therefore, we have (a) designed hydroxylated amide-linked galactosides, (b) performed preliminary docking studies on model structures, (c) synthesized mono and divalent ligands grafted on different scaffolds, (d) determined their affinities toward PNA lectin by ELLA, and finally, (e) accomplished molecular dynamic simulations to rationalize the obtained results from a structural dynamics viewpoint.

Globally analyzed these results are in accordance with our initial hypothesis that a hydroxyl group properly disposed could mimic the Glc $\mathrm{O} 3$ in the recognition process.

Regarding the multivalent effect, divalent species showed an increased affinity with respect to their monomeric counterparts. Even though bidendate binding is not possible as the linkers are not long enough to span the distance between two binding sites in the tetrameric lectin $(57-79 \AA)[12,42]$, the most interesting result is the notable cluster effect observed for some of them. Probably, for divalent compounds, the "bind and recapture" mechanism could be operating [1-3]. 
A
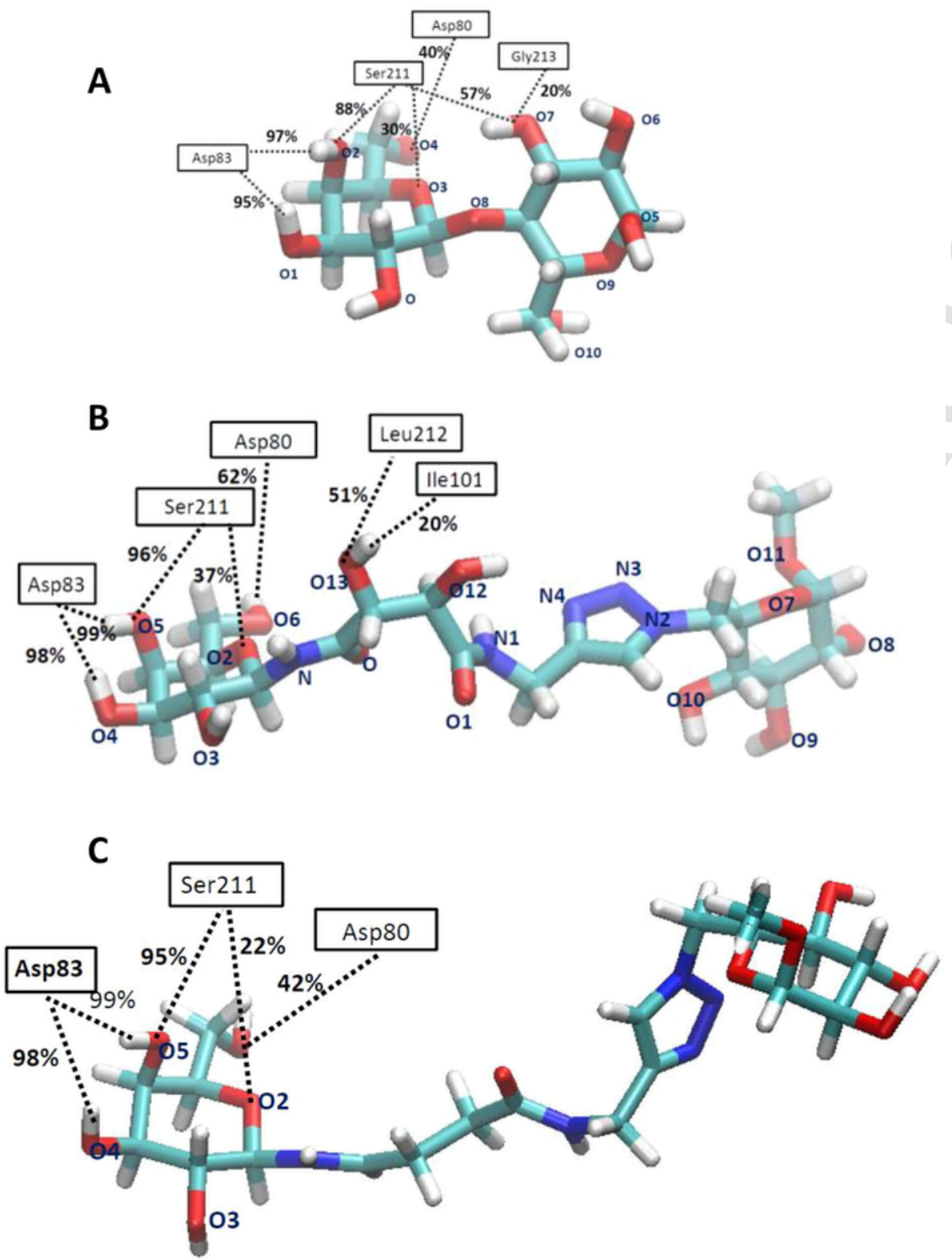

Fig. 7. Hydrogen bond analysis which characterize the protein-ligand contacts in: (A) lactose-PNA complex; (B) compound 12-PNA complex and (C) compound 13-PNA complex [41].

\section{Experimental}

\subsection{General methods}

Analytical thin layer chromatography (TLC) was performed on Silica Gel 60 F254 aluminum supported plates (layer thickness $0.2 \mathrm{~mm}$ ) with solvent systems given in the text. Visualization of the spots was effected by exposure to UV light and charring with a solution of 5\% $(\mathrm{v} / \mathrm{v})$ sulfuric acid in $\mathrm{EtOH}$, containing $0.5 \% p$-anisaldehyde. Column chromatography was carried out with Silica Gel 60 (230-400 mesh). Optical rotations were measured at $20^{\circ} \mathrm{C}$ in a $1 \mathrm{dm}$ cell with a Perkin-Elmer 343 polarimeter. Microwave irradiation was carried out in a CEM Discover MW instrument with a System Inter- nal IR probe type, at $70^{\circ} \mathrm{C}$ (power max $300 \mathrm{~W}$ ). High resolution mass spectra (HRMS) were obtained by Electrospray Ionization (ESI) and Q-TOF. ${ }^{1} \mathrm{H}$ and ${ }^{13} \mathrm{C}$ nuclear magnetic resonance (NMR) spectra were recorded at $25^{\circ} \mathrm{C}$ at 500 and $125.7 \mathrm{MHz}$, respectively, using a Bruker Avance II 500 spectrometer. For ${ }^{1} \mathrm{H},{ }^{13} \mathrm{C}$ nuclear magnetic resonance (NMR) spectra, chemical shifts are reported in parts per million relative to tetramethylsilane or a residual solvent peak $\left(\mathrm{CHCl}_{3}:{ }^{1} \mathrm{H}: \delta\right.$ $\left.7.26 \mathrm{ppm},{ }^{13} \mathrm{C}: \delta 77.2 \mathrm{ppm}\right)$. Assignments of ${ }^{1} \mathrm{H}$ and ${ }^{13} \mathrm{C}$ were assisted by $2 \mathrm{D}{ }^{1} \mathrm{H}-\mathrm{COSY}$ and $2 \mathrm{D}{ }^{1} \mathrm{H}-{ }^{13} \mathrm{C}$ experiments. In the description of the spectra, the signals corresponding to the glucose or trehalose moieties were labeled as "G" or "T", respectively. Azide-sugar scaffolds 7 and 8 , and compounds $13,16,25$ and 26 were prepared as previously reported [33]. 
4.2.1. 2,3-Di-O-acetyl-N-(2,3,4,6-tetra-O-acetyl- $\beta$-D-galactopyranosyl)-Lacid monoamide (4)

To a solution of 2,3,4,6-tetra- $O$-acetyl- $\beta$-D-galactosylamine (2) (389 mg, $1.12 \mathrm{mmol})$ in anhydrous $\mathrm{MeCN}(1.3 \mathrm{~mL})$, was added $(R, R)$-tartaric anhydride [43] $(1.34 \mathrm{mmol}, 290 \mathrm{mg})$. The reaction proceeded for $15 \mathrm{~min}$, when TLC showed complete consumption of the starting 2 . The solution was evaporated and compound 4 was purified by column chromatography, using Toluene: EtOAc (2: 1) to AcOEt: $\mathrm{MeOH}$ (7: 3) containing 1\% AcOH as eluting solvents. Yield: $478 \mathrm{mg}(76 \%) ;[\alpha]_{\mathrm{D}}{ }^{20}+30.7\left(c 0.5, \mathrm{CHCl}_{3}\right) ; R_{\mathrm{f}} 0.24\left(\mathrm{CHCl}_{3}: \mathrm{MeOH}\right.$ 10:1); ${ }^{1} \mathrm{H}$ NMR $\left(\mathrm{CDCl}_{3}\right): \delta 7.03\left(\mathrm{~d}, 1 \mathrm{H}, J_{1, \mathrm{NH}} 9.2 \mathrm{~Hz}, \mathrm{NH}\right), 6.28(\mathrm{br}$ s, $1 \mathrm{H}, \mathrm{OH}), 5.70\left(\mathrm{~d}, 1 \mathrm{H}, J_{\mathrm{CHa}, \mathrm{CHb}} 2.6 \mathrm{~Hz}, \mathrm{CHa}\right), 5.68\left(\mathrm{~d}, 1 \mathrm{H}, J_{\mathrm{CHa}, \mathrm{CHb}}\right.$ $2.6 \mathrm{~Hz}, \mathrm{CHb}), 5.45$ (dd, $\left.1 \mathrm{H}, J_{4,5} 0.7, J_{3,4} 3.0 \mathrm{~Hz}, \mathrm{H}-4\right), 5.17-5.07$ (m, 3H, H-1, H-2, H-3), 4.10-4.03 (m, 3H, H-5, H-6a, H-6b), 2.25, 2.15, 2.13, $2.02(2 \mathrm{x}), 1.99\left(6 \mathrm{~s}, 18 \mathrm{H}, \mathrm{CH}_{3} \mathrm{CO}\right) .{ }^{13} \mathrm{C} \mathrm{NMR}\left(\mathrm{CDCl}_{3}\right): \delta$ $172.2,170.7,170.2,169.9,169.5,169.4,169.3,167.1(8 \times C O), 78.5$ (C-1), 72.6 (C-5), $72.3(\mathrm{CHb}), 70.6$ (CHa), 71.5 (C-3), 67.9 (C-2), 67.3 (C-4), 61.1 (C-6), 20.7 (3x), 20.6, 20.2 ( $\left.\mathrm{CH}_{3} \mathrm{CO}\right)$. HRMS (ESI): $m / z[M+\mathrm{Na}]^{+}$calcd for $\mathrm{C}_{22} \mathrm{H}_{29} \mathrm{NNaO}_{16}: 586.1379$, found: 586.1401 .

\subsubsection{2,3-Di-O-acetyl- $N$-(2,3,4,6-tetra-O-acetyl- $\beta$-D-galactopyranosyl)- $N$ -} diamide (5)

To a solution of $4(0.85 \mathrm{mmol}, 480 \mathrm{mg})$ in anh $\mathrm{CH}_{2} \mathrm{Cl}_{2}, \mathrm{DCC}$ (1.07 mmol, $220 \mathrm{mg}$ ) was added under Ar atmosphere. After stirring for $20 \mathrm{~min}$, propargylamine $(1.02 \mathrm{mmol}, 56.4 \mathrm{mg})$ was added and the mixture was stirred at room temperature for $24 \mathrm{~h}$ and then filtered. The solution was concentrated and the products purified by column chromatography using $\mathrm{CHCl}_{3}$ : $\mathrm{MeOH}(50: 1$ to $35: 1)$ as eluting solvents. Yield: $430 \mathrm{mg}(84 \%)$; $\mathrm{mp} 107-111^{\circ} \mathrm{C}$; $[\alpha]_{\mathrm{D}}{ }^{20}+46.5$ (c 1.0, $\left.\mathrm{CHCl}_{3}\right) ; R_{\mathrm{f}} 0.46\left(\mathrm{CHCl}_{3}: \mathrm{MeOH} 10: 1\right) ;{ }^{1} \mathrm{H} \mathrm{NMR}\left(\mathrm{CDCl}_{3}\right): \delta 6.95$ $\left(\mathrm{d}, 1 \mathrm{H}, J_{1, \mathrm{NH}} 9.2 \mathrm{~Hz}, \mathrm{NH}\right), 6.49\left(\mathrm{t}, 1 \mathrm{H}, J_{\mathrm{CH} 2, \mathrm{NH}} 5.4 \mathrm{~Hz}, \mathrm{NH}\right), 5.79$ (d, $\left.1 \mathrm{H}, J_{\mathrm{CHa}, \mathrm{CHb}} 2.5 \mathrm{~Hz}, \mathrm{CHa}\right), 5.62\left(\mathrm{~d}, 1 \mathrm{H}, J_{\mathrm{CHa}, \mathrm{CHb}} 2.5 \mathrm{~Hz}, \mathrm{CHb}\right)$, $5.43\left(\mathrm{~d}, 1 \mathrm{H}, J_{3,4} 3.2 \mathrm{~Hz}, \mathrm{H}-4\right), 5.15$ (dd, $J_{3,4} 3.4, J_{2,3} 10.2 \mathrm{~Hz}, \mathrm{H}-3$ ), $5.13\left(\mathrm{t}, 1 \mathrm{H}, J_{1,2}=J_{1, \mathrm{NH}} 9.2 \mathrm{~Hz}, \mathrm{H}-1\right), 5.06\left(\mathrm{t}, 1 \mathrm{H}, J_{1,2}=J_{2,3} 9.7 \mathrm{~Hz}\right.$, $\mathrm{H}-2$ ), 4.17 (ddd, $1 \mathrm{H}, J_{\mathrm{CH} 2, \mathrm{C}} \equiv_{\mathrm{CH}} 2.5, J_{\mathrm{CH} 2, \mathrm{NH} 2} 6.2, J_{\mathrm{gem}} 17.5 \mathrm{~Hz}$, $\mathrm{CH}_{2} \mathrm{~N}$ ), 4.09-4.02 (m, 3H, H-5, H-6a, H-6b), 3.92 (ddd, $1 \mathrm{H}, J_{\mathrm{CH} 2 . \mathrm{C}}$ $\left.\equiv_{\mathrm{CH}} 2.5, J_{\mathrm{CH} 2 . \mathrm{NH} 2} 4.7, J_{\mathrm{gem}} 17.5 \mathrm{~Hz}, \mathrm{CH}_{2} \mathrm{~N}\right), 2.25\left(\mathrm{t}, 1 \mathrm{H}, J_{\mathrm{CH} 2, \mathrm{C}} \equiv\right.$ $\left.{ }_{\mathrm{CH}} 2.5 \mathrm{~Hz}, \mathrm{C} \equiv \mathrm{CH}\right), 2.20,2.15,2.13,2.02,2.00,1.98(6 \mathrm{~s}, 18 \mathrm{H}$, $\left.\mathrm{CH}_{3} \mathrm{CO}\right) .{ }^{13} \mathrm{C}$ NMR $\left(\mathrm{CDCl}_{3}\right): \delta 172.2,170.6,170.0,169.8,169.2$, 168.7, 167.1, $165.6(8 \times C \mathrm{O}), 79.0(\mathrm{HC} \equiv \mathrm{C}), 78.3(\mathrm{C}-1), 73.0(\mathrm{CHa})$, 72.5 (C-5), $72.1(\mathrm{HC} \equiv \mathrm{C}), 72.0(\mathrm{CHb}), 70.5$ (C-3), $67.8(\mathrm{C}-2), 67.3$ (C-4), $61.1(\mathrm{C}-6), 29.2\left(\mathrm{CH}_{2} \mathrm{~N}\right), 20.7(3 \mathrm{x}), 20.6(2 \mathrm{x}), 20.5\left(\mathrm{CH}_{3} \mathrm{CO}\right)$. HRMS (ESI): $m / z[M+\mathrm{H}]^{+}$calcd for $\mathrm{C}_{25} \mathrm{H}_{33} \mathrm{~N}_{2} \mathrm{O}_{15}$ : 601.1875, found: 601.1877 .

\subsection{General procedure for the click reaction}

The click reaction was conducted under the conditions previously described [33]. The azide/derivatives $7, \mathbf{8 , 9}$ or $10(0.20 \mathrm{mmol})$ and the alkynyl derivatives 5 or $\mathbf{6}(0.20 \mathrm{mmol}$ per mole of reacting azide) were dissolved in a dioxane $/ \mathrm{H}_{2} \mathrm{O}$ mixture $(8: 2,2.5 \mathrm{~mL})$. Copper sulfate $(0.05 \mathrm{mmol}$ per mole of reacting azide) and sodium ascorbate ( $0.10 \mathrm{mmol}$ per mole of azide group) were added, and the mixture was stirred at $70{ }^{\circ} \mathrm{C}$ under microwave irradiation during $40 \mathrm{~min}$. The mixture was then poured into a $1: 1 \mathrm{NH}_{4} \mathrm{Cl} / \mathrm{H}_{2} \mathrm{O}$ solution $(20 \mathrm{~mL})$ and extracted with EtOAc $(4 \times 15 \mathrm{~mL})$. The organic layer was dried $\left(\mathrm{Na}_{2} \mathrm{SO}_{4}\right)$ and filtered, and the solvent was evaporated under reduced pressure. The residue was purified by flash chromatography, using the solvent systems indicated in each case.
2,3,4-tri-O-acetyl-6-deoxy-6-\{4-[2,3-di-O-acetyl-N'-(2,3,4,6-tetra-O-acetyl- $\beta$ - $D$

-tatlfagilacopyranoside (11)

Compound 11 was obtained by reaction of $\mathbf{5}$ and 7. Column solvent system: $\mathrm{CHCl}_{3}$ : $\mathrm{MeOH}(50: 1$ to $35: 1), 176 \mathrm{mg}(93 \%) ; \mathrm{mp}$ $124-126^{\circ} \mathrm{C} ;[\alpha]_{\mathrm{D}}{ }^{20}+76.9\left(\mathrm{c} 1.0, \mathrm{CHCl}_{3}\right) ; R_{\mathrm{f}} 0.53\left(\mathrm{CHCl}_{3}: \mathrm{MeOH}\right.$ 9:1); ${ }^{1} \mathrm{H}$ NMR $\left(\mathrm{CDCl}_{3}\right): \delta 7.66\left(\mathrm{~s}, 1 \mathrm{H}, \mathrm{H}\right.$-triazole), $6.91\left(\mathrm{~d}, 1 \mathrm{H}, J_{1, \mathrm{NH}}\right.$ $8.9 \mathrm{~Hz}, \mathrm{~N} H), 6.83\left(\mathrm{t}, 1 \mathrm{H}, J_{\mathrm{CH} 2, \mathrm{NH} 2} 5.7 \mathrm{~Hz}, \mathrm{NH}\right), 5.75\left(\mathrm{~d}, 1 \mathrm{H}, J_{\mathrm{CHa}, \mathrm{CHb}}\right.$ $2.4 \mathrm{~Hz}, \mathrm{CHa}), 5.60$ (d, 1H, $\left.J_{\mathrm{CHa}, \mathrm{CHb}} 2.4 \mathrm{~Hz}, \mathrm{CHb}\right), 5.47$ (dd, 1H, $J_{3 \mathrm{G}, 4 \mathrm{G}}$ 9.3, $\left.J_{2 \mathrm{G}, 3 \mathrm{G}} 10.2 \mathrm{~Hz}, \mathrm{H}-3 \mathrm{G}\right), 5.44$ (dd, $\left.1 \mathrm{H}, J_{4,5} 0.8, J_{3,4} 3.5 \mathrm{~Hz}, \mathrm{H}-4\right)$, $5.13\left(\mathrm{dd}, 1 \mathrm{H}, J_{3,4} 3.5, J_{2,3} 10.3 \mathrm{~Hz}, \mathrm{H}-3\right), 5.12\left(\mathrm{t}, 1 \mathrm{H}, J_{1,2}=J_{1, \mathrm{NH}}\right.$ $8.8 \mathrm{~Hz}, \mathrm{H}-1), 5.07$ (dd, 1H, $\left.J_{1,2} 9.3, J_{2,3} 10.0 \mathrm{~Hz}, \mathrm{H}-2\right), 4.92$ (d, $1 \mathrm{H}$, $\left.J_{1 \mathrm{G}, 2 \mathrm{G}} 3.6 \mathrm{~Hz}, \mathrm{H}-1 \mathrm{G}\right), 4.83\left(\mathrm{dd}, 1 \mathrm{H}, J_{1 \mathrm{G}, 2 \mathrm{G}} 3.7, J_{2 \mathrm{G}, 3 \mathrm{G}} 10.3 \mathrm{~Hz}, \mathrm{H}-2 \mathrm{G}\right)$, $4.78\left(\mathrm{dd}, 1 \mathrm{H}, J_{3 \mathrm{G}, 4 \mathrm{G}} 9.3, J_{4 \mathrm{G}, 5 \mathrm{G}} 10.2 \mathrm{~Hz}, \mathrm{H}-4 \mathrm{G}\right), 4.54\left(\mathrm{dd}, 1 \mathrm{H}, J_{\mathrm{CH} 2, \mathrm{NH}}\right.$ 5.9, $\left.J_{\text {gem }} 15.2 \mathrm{~Hz}, \mathrm{CH}_{2} \mathrm{~N}\right), 4.53\left(\mathrm{dd}, 1 \mathrm{H}, J_{5,6 \mathrm{aG}} 2.4, J_{6 \mathrm{aG}, 6 \mathrm{bG}} 14.4 \mathrm{~Hz}\right.$, $\mathrm{H}-6 \mathrm{aG}), 4.49$ (dd, $\left.1 \mathrm{H}, J_{\mathrm{CH} 2, \mathrm{NH}} 5.9, J_{\mathrm{gem}} 15.3 \mathrm{~Hz}, \mathrm{CH}_{2} \mathrm{~N}\right), 4.41(\mathrm{dd}, 1 \mathrm{H}$, $\left.J_{5,6 \mathrm{bG}} 7.8, J_{6 \mathrm{aG}, 6 \mathrm{bG}} 14.4 \mathrm{~Hz}, \mathrm{H}-6 \mathrm{bG}\right), 4.16\left(\mathrm{ddd}, 1 \mathrm{H}, J_{5 \mathrm{G}, 6 \mathrm{aG}} 2.4, J_{5 \mathrm{G}, 6 \mathrm{bG}}\right.$ 7.9, $\left.J_{4 \mathrm{G}, 5 \mathrm{G}} 10.2 \mathrm{~Hz}, \mathrm{H}-5 \mathrm{G}\right), 4.10\left(\mathrm{dd}, 1 \mathrm{H}, J_{5,6 \mathrm{a}} 8.8, J_{6 \mathrm{a}, 6 \mathrm{~b}} 12.8 \mathrm{~Hz}\right.$, H-6a), 4.04 (dd, 1H, $J_{5,6 \mathrm{~b}} 6.1, J_{6 \mathrm{a}, 6 \mathrm{~b}} 12.8 \mathrm{~Hz}, \mathrm{H}-6 \mathrm{~b}$ ), 4.03 (ddd, 1H, $\left.J_{4,5} 1.0, J_{5,6 \mathrm{~b}} 6.1, J_{5,6 \mathrm{a}} 8.2 \mathrm{~Hz}, \mathrm{H}-5\right), 3.17\left(\mathrm{~s}, 3 \mathrm{H}, \mathrm{OCH}_{3}\right), 2.15,2.14$, 2.12, 2.10, 2.06, 2.03, $2.00(2 \mathrm{x}), 1.99\left(9 \mathrm{~s}, 27 \mathrm{H}, \mathrm{CH}_{3} \mathrm{CO}\right) .{ }^{13} \mathrm{C} \mathrm{NMR}$ $\left(\mathrm{CDCl}_{3}\right): \delta 172.0,170.4,170.1,169.9(2 \mathrm{x}), 169.7,169.6,169.0,168.6$,

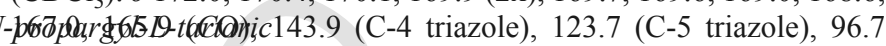
(C-1G), 78.3 (C-1), 72.7 (CHa), 72.5 (C-5), 72.1 (CHb), 70.5 (C-2G), 70.4 (C-3G), 69.8, 69.7 (C-3, C-4G), 67.7 (2x) (C-2, C-5G), 67.1 (C-4), $60.9(\mathrm{C}-6), 55.6\left(\mathrm{OCH}_{3}\right), 50.7(\mathrm{C}-6 \mathrm{G}), 34.8\left(\mathrm{CH}_{2} \mathrm{~N}\right), 20.7(2 \mathrm{x})$, $20.6(4 \mathrm{x}), 20.5,20.4(2 \mathrm{x})\left(\mathrm{CH}_{3} \mathrm{CO}\right)$. HRMS (ESI): $m / z[M+\mathrm{Na}]^{+}$calcd for $\mathrm{C}_{38} \mathrm{H}_{51} \mathrm{~N}_{5} \mathrm{NaO}_{23}$ : 968.2873 , found: 968.2849.

\subsubsection{2,2',3,3',4,4'-Hexa-O-acetyl-6,6'-dideoxy-6,6'-bis-\{4-[2,3-di-O-acetyl-N'- $\alpha, \alpha^{\prime}$-trehalose (14)}

Compound 14 was obtained by reaction of 5 and 8 . Column solvent system: $\mathrm{CHCl}_{3}$ : $\mathrm{MeOH}$ (50: 1 to $\left.20: 1\right), 170 \mathrm{mg}(46 \%) ; \mathrm{mp}$ $141-143{ }^{\circ} \mathrm{C} ;[\alpha]_{\mathrm{D}}{ }^{20}+46.2\left(c 1.0, \mathrm{CHCl}_{3}\right) ; R_{\mathrm{f}} 0.52\left(\mathrm{CHCl}_{3}: \mathrm{MeOH}\right.$ 9:1); ${ }^{1} \mathrm{H} \mathrm{NMR}\left(\mathrm{CDCl}_{3}\right): \delta 7.63(\mathrm{~s}, 1 \mathrm{H}, \mathrm{H}$-triazole $), 7.03-7.01(\mathrm{~m}, 2 \mathrm{H}$, $2 \times \mathrm{NH}), 5.68\left(\mathrm{~d}, 1 \mathrm{H}, J_{\mathrm{CHa}, \mathrm{CHb}} 1.8 \mathrm{~Hz}, \mathrm{CHa}\right), 5.60\left(\mathrm{~d}, 1 \mathrm{H}, J_{\mathrm{CHa}, \mathrm{CHb}}\right.$ $1.9 \mathrm{~Hz}, \mathrm{CHb}), 5.44\left(\mathrm{~d}, 1 \mathrm{H}, J_{3,4} 2.2 \mathrm{~Hz}, \mathrm{H}-4\right), 5.42\left(\mathrm{t}, 1 \mathrm{H}, J_{3 \mathrm{~T}, 4 \mathrm{~T}}=J_{2 \mathrm{~T}, 3 \mathrm{~T}}\right.$ $10.0 \mathrm{~Hz}, \mathrm{H}-3 \mathrm{~T}$ ), 5.17 (dd, $1 \mathrm{H}, J_{3,4} 3.6, J_{2,3} 10.6 \mathrm{~Hz}, \mathrm{H}-3$ ), 5.16 (dd, $\left.1 \mathrm{H}, J_{1,2} 9.3, J_{2,3} 10.6 \mathrm{~Hz}, \mathrm{H}-2\right), 5.11\left(\mathrm{t}, 1 \mathrm{H}, J_{1,2} 9.7 \mathrm{~Hz}, \mathrm{H}-1\right), 5.06$ (dd, $\left.1 \mathrm{H}, J_{1 \mathrm{~T}, 2 \mathrm{~T}} 3.5, J_{2 \mathrm{~T}, 3 \mathrm{~T}} 10.5 \mathrm{~Hz}, \mathrm{H}-2 \mathrm{~T}\right), 4.97\left(\mathrm{t}, 1 \mathrm{H}, J_{3 \mathrm{~T}, 4 \mathrm{~T}}=J_{4 \mathrm{~T}, 5 \mathrm{~T}} 9.8 \mathrm{~Hz}\right.$, $\mathrm{H}-4 \mathrm{~T}), 4.92\left(\mathrm{~d}, 1 \mathrm{H}, J_{1 \mathrm{~T}, 2 \mathrm{~T}} 3.4 \mathrm{~Hz}, \mathrm{H}-1 \mathrm{~T}\right), 4.59-4.49\left(\mathrm{~m}, 3 \mathrm{H}, \mathrm{CH}_{2} \mathrm{~N}\right.$, H-6aT), 4.29 (dd, 1H, $\left.J_{5 \mathrm{~T}, 6 \mathrm{bT}} 9.1, J_{6 \mathrm{aT}, 6 \mathrm{bT}} 14.3 \mathrm{~Hz}, \mathrm{H}-6 \mathrm{bT}\right), 4.07-4.00$ (m, 4H, H-5T + H-5 + H-6a + H-6b), 2.21, 2.14 (2x), 2.11, 2.01 (2x), $2.00,1.99,1.96\left(9 \mathrm{~s}, 27 \mathrm{H}, \mathrm{CH}_{3} \mathrm{CO}\right) .{ }^{13} \mathrm{C} \mathrm{NMR}\left(\mathrm{CDCl}_{3}\right): \delta 172.2$, $170.5,170.3,170.1,169.9(2 \mathrm{x}), 169.8,169.5,169.4,169.3,165.8$ (CO), 144.8 (C-4 triazole); 123.7 (C-5 triazole), $91.6(\mathrm{C}-1 \mathrm{~T}), 78.5$ (C-1), 72.9 (CHb), 72.4 (C-5), 72.2 (CHa), 70.5 (C-3), 69.7 (C-4T), 69.6 (C-5T), 69.5 (C-3T), 69.1 (C-2T), 67.9 (C-2), 67.2 (C-4), 60.9 (C-6), $50.7(\mathrm{C}-6 \mathrm{~T}), 35.2\left(\mathrm{CH}_{2} \mathrm{~N}\right), 20.9,20.8,20.7(6 \mathrm{x}), 20.6\left(\mathrm{COCH}_{3}\right)$. HRMS (ESI) m/z [M $+\mathrm{Na}]^{+}$calcd for $\mathrm{C}_{74} \mathrm{H}_{96} \mathrm{~N}_{10} \mathrm{NaO}_{45}$ 1867.5429, found 1867.5436 .

\subsubsection{1,4:3,6-Dianhydro-2,5-dideoxy-2,5-bis-\{4-[2,3-di-O-acetyl-N-(2,3,4,6-tet} (17)

Compound 17 was obtained by reaction of $\mathbf{5}$ and $\mathbf{9}$. Column solvent system: $\mathrm{CHCl}_{3}$ : $\mathrm{MeOH}$ (50: 1 to $\left.25: 1\right), 151 \mathrm{mg}(54 \%)$; $\mathrm{mp}$ $156-158^{\circ} \mathrm{C} ;[\alpha]_{\mathrm{D}}{ }^{20}+63.2\left(c 1.0, \mathrm{CHCl}_{3}\right) ; R_{\mathrm{f}} 0.27\left(\mathrm{CHCl}_{3}: \mathrm{MeOH}\right.$ 9:1); ${ }^{1} \mathrm{H}$ NMR $\left(\mathrm{CDCl}_{3}\right): \delta 7.68(\mathrm{~s}, 1 \mathrm{H}, \mathrm{H}$-triazole $), 7.10(\mathrm{t}, 1 \mathrm{H}$, 
$\left.J_{\mathrm{CH} 2 \mathrm{NH}} 5.9 \mathrm{~Hz}, \mathrm{~N} H\right), 7.04\left(\mathrm{~d}, 1 \mathrm{H}, J_{1, \mathrm{NH}} 9.1 \mathrm{~Hz}, \mathrm{~N} H\right), 5.71(\mathrm{~d}, 1 \mathrm{H}$, $\left.J_{\mathrm{CHa}, \mathrm{CHb}} 2.5 \mathrm{~Hz}, \mathrm{CHa}\right), 5.61\left(\mathrm{~d}, 1 \mathrm{H}, J_{\mathrm{CHa}, \mathrm{CHb}} 2.5 \mathrm{~Hz}, \mathrm{CHb}\right), 5.44$ (d, $\left.1 \mathrm{H}, J_{3,4} 3.4 \mathrm{~Hz}, \mathrm{H}-4\right), 5.22$ (dd, $1 \mathrm{H}, J_{2^{\prime}}, 3 \mathrm{a}^{\prime} 2.7, J_{2^{\prime}, 3 \mathrm{~b}^{\prime}} 5.3 \mathrm{~Hz}, \mathrm{H}-2^{\prime}$ ), $5.18\left(\mathrm{dd}, 1 \mathrm{H}, J_{3,4} 3.4, J_{2,3} 10.2 \mathrm{~Hz}, \mathrm{H}-3\right), 5.14\left(\mathrm{t}, 1 \mathrm{H}, J_{1,2}=J_{1, \mathrm{NH}}\right.$ $9.2 \mathrm{~Hz}, \mathrm{H}-1), 5.13$ (s, 1H, H-1'), 5.08 (dd, $1 \mathrm{H}, J_{1,2} 9.2, J_{2,3} 10.2 \mathrm{~Hz}$, $\mathrm{H}-2), 4.53$ (dd, $\left.1 \mathrm{H}, J_{\mathrm{CH} 2, \mathrm{NH} 2} 6.0, J_{\text {gem }} 15.3 \mathrm{~Hz}, \mathrm{CH}_{2} \mathrm{~N}\right), 4.41$ (dd, $1 \mathrm{H}$, $\left.J_{\mathrm{CH} 2, \mathrm{NH} 2} 5.9, J_{\text {gem }} 15.3 \mathrm{~Hz}, \mathrm{CH}_{2} \mathrm{~N}\right), 4.38\left(\mathrm{dd}, 1 \mathrm{H}, J_{2^{\prime}, 3 \mathrm{a}^{\prime}} 5.4, J_{3 \mathrm{a}^{\prime}, 3 \mathrm{~b}^{\prime}}\right.$ $\left.10.4 \mathrm{~Hz}, \mathrm{H}-3 \mathrm{a}^{\prime}\right), 4.29\left(\mathrm{dd}, 1 \mathrm{H}, J_{2^{\prime}, 3 \mathrm{~b}^{\prime}} 2.6, J_{3 \mathrm{a}^{\prime}, 3 \mathrm{~b}^{\prime}} 10.4 \mathrm{~Hz}, \mathrm{H}-3 \mathrm{~b}^{\prime}\right)$, 4.09-4.03 (m, 3H, H-5, H-6a, H-6b), 2.14, 2.13, 2.08, 2.02, 2.00, 1.99 $\left(6 \mathrm{~s}, 18 \mathrm{H}, \mathrm{CH}_{3} \mathrm{CO}\right) .{ }^{13} \mathrm{C} \mathrm{NMR}\left(\mathrm{CDCl}_{3}\right): \delta 172.0,170.4,169.9,169.7$, 169.1, 168.8, 167.1, 166.1 (CO), 144.6 (C-4 triazole), 122.0 (C-5 triazole), 87.5 (C-1'), 78.3 (C-1), 72.6, 72.5, 72.4, 72.1 (C-5, C-3', CHa, CHb), 70.4 (C-3), 67.8 (C-2), 67.1 (C-4), 65.7 (C-2'), 60.9 (C-6), $34.7\left(\mathrm{CH}_{2} \mathrm{~N}\right), 20.6(3 \mathrm{x}), 20.5,20.4(2 \mathrm{x})\left(\mathrm{CH}_{3} \mathrm{CO}\right)$. HRMS (ESI): $\mathrm{m} / z$ $[M+\mathrm{Na}]^{+}$calcd for $\mathrm{C}_{56} \mathrm{H}_{72} \mathrm{~N}_{10} \mathrm{NaO}_{32}: 1419.4206$, found: 1419.4158 .
4.3.6. 2,2'-bis-\{4-[N-(2,3,4,6-tetra-O-acetyl- $\beta$-D-galactopyranosyl)-succinamoy (23)

Compound 23 was obtained by reaction of $\mathbf{6}$ and 10. Column solvent system: EtOAc to EtOAc: $\mathrm{MeOH}$ (80: 20), $135 \mathrm{mg}(60 \%)$; $[\alpha]_{\mathrm{D}}{ }^{20}+20.3\left(c 0.3, \mathrm{CHCl}_{3}\right) ; R_{\mathrm{f}} 0.12$ (EtOAc: $\left.\mathrm{MeOH} 9: 1\right) ;{ }^{1} \mathrm{H}$ NMR $\left(\mathrm{CDCl}_{3}\right): \delta 7.69$ (br s, $1 \mathrm{H}, \mathrm{H}$-triazole), 7.47 (br s, $\left.1 \mathrm{H}, \mathrm{NH}\right), 7.04$ $\left(\mathrm{d}, 1 \mathrm{H}, J_{1, \mathrm{NH}} 9.2 \mathrm{~Hz}, \mathrm{NH}\right), 5.42\left(\mathrm{~d}, 1 \mathrm{H}, J_{3,4} 1.8 \mathrm{~Hz}, \mathrm{H}-4\right), 5.28$ (t, $\left.1 \mathrm{H}, J_{1,2}=J_{1, \mathrm{NH}} 9.0 \mathrm{~Hz}, \mathrm{H}-1\right), 5.16\left(\mathrm{dd}, 1 \mathrm{H}, J_{3,4} 1.9, J_{2,3} 10.4 \mathrm{~Hz}\right.$, $\mathrm{H}-3), 5.11\left(\mathrm{t}, 1 \mathrm{H}, J_{1,2}=J_{2,3} 9.7 \mathrm{~Hz}, \mathrm{H}-2\right), 4.58-4.32\left(\mathrm{~m}, 4 \mathrm{H}, \mathrm{CH}_{2} \mathrm{~N}\right.$, $\left.\mathrm{CH}_{2} \mathrm{Ar}\right), 4.11-4.02(\mathrm{~m}, 3 \mathrm{H}, \mathrm{H}-5, \mathrm{H}-6 \mathrm{a}, \mathrm{H}-6 \mathrm{~b}), 3.84-3.72(\mathrm{~m}, 2 \mathrm{H}$, $\left.\mathrm{CH}_{2} \mathrm{O}\right), 2.66-2.46\left(\mathrm{~m}, 4 \mathrm{H}, \mathrm{CH}_{2}-\mathrm{CH}_{2}\right), 2.12,2.02,2.00,1.96$ (4 s, $\left.12 \mathrm{H}, \mathrm{CH}_{3} \mathrm{CO}\right) .{ }^{13} \mathrm{C} \mathrm{NMR}\left(\mathrm{CDCl}_{3}\right): \delta 172.9,172.1,171.1,170.5$, 170.2, 169.9 (CO), 78.5 (C-1), $72.4(\mathrm{C}-5), 71.1,(\mathrm{C}-3), 69.2\left(\mathrm{CH}_{2} \mathrm{O}\right)$, $68.3(\mathrm{C}-2), 67.3(\mathrm{C}-4), 61.2(\mathrm{C}-6), 50.3\left(\mathrm{CH}_{2} \mathrm{Ar}\right), 35.1\left(\mathrm{CH}_{2} \mathrm{~N}\right), 31.3$, $30.6\left(\mathrm{CH}_{2}-\mathrm{CH}_{2}\right), 20.8(2 \mathrm{x}), 20.7,20.6\left(\mathrm{CH}_{3} \mathrm{CO}\right)$. HRMS (ESI): $\mathrm{m} / z$ $[M+\mathrm{Na}]^{+}$calcd for $\mathrm{C}_{46} \mathrm{H}_{64} \mathrm{~N}_{10} \mathrm{NaO}_{23}: 1147.4043$, found: 1147.4001 .

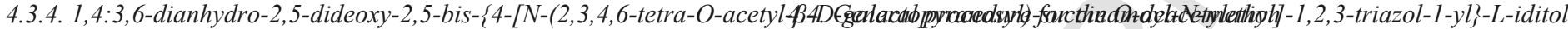
(19)

Compound 19 was obtained by reaction of 6 and 9. Column solvent system: $\mathrm{CHCl}_{3}$ : $\mathrm{MeOH}$ (50: 1 to 20: 1), $182 \mathrm{mg}(78 \%)$; $\mathrm{mp}$ $136-138{ }^{\circ} \mathrm{C} ;[\alpha]_{\mathrm{D}}{ }^{20}+56.7\left(c 1.0, \mathrm{CHCl}_{3}\right) ; R_{\mathrm{f}} 0.33\left(\mathrm{CHCl}_{3}: \mathrm{MeOH}\right.$ 9:1); ${ }^{1} \mathrm{H}$ NMR $\left(\mathrm{CDCl}_{3}\right): \delta 7.66(\mathrm{~s}, 1 \mathrm{H}, \mathrm{H}$-triazole $), 6.78(\mathrm{~m}, 2 \mathrm{H}$, $2 \times \mathrm{NH}), 5.44\left(\mathrm{~d}, 1 \mathrm{H}, J_{3,4} 3.4 \mathrm{~Hz}, \mathrm{H}-4\right), 5.29\left(\mathrm{t}, 1 \mathrm{H}, J_{1,2}=J_{1, \mathrm{NH}} 9.3 \mathrm{~Hz}\right.$, $\mathrm{H}-1), 5.29\left(\mathrm{dd}, 1 \mathrm{H}, J_{2^{\prime}, 3 \mathrm{a}^{\prime}} 2.3, J_{2^{\prime}, 3 \mathrm{~b}^{\prime}} 5.6 \mathrm{~Hz}, \mathrm{H}-2^{\prime}\right), 5.23(\mathrm{dd}, 1 \mathrm{H}$, $\left.J_{3,4} 3.4, J_{2,3} 10.2 \mathrm{~Hz}, \mathrm{H}-3\right), 5.12\left(\mathrm{t}, 1 \mathrm{H}, J_{1,2}=J_{2,3} 9.3 \mathrm{~Hz}, \mathrm{H}-2\right), 5.09$ $\left(\mathrm{s}, 1 \mathrm{H}, \mathrm{H}-1^{\prime}\right), 4.54\left(\mathrm{dd}, 1 \mathrm{H}, J_{\mathrm{CH} 2 \mathrm{NH}} 6.0, J_{\text {gem }} 15.4 \mathrm{~Hz}, \mathrm{CH}_{2} \mathrm{~N}\right), 4.41$ $\left(\mathrm{dd}, 1 \mathrm{H}, J_{\mathrm{CH} 2, \mathrm{NH} 2} 5.6, J_{\text {gem }} 15.2 \mathrm{~Hz}, \mathrm{CH}_{2} \mathrm{~N}\right), 4.40\left(\mathrm{dd}, 1 \mathrm{H}, J_{2^{\prime}, 3 \mathrm{a}^{\prime}} 5.2\right.$, $\left.J_{3 \mathrm{a}^{\prime}, 3 \mathrm{~b}^{\prime}} 10.4 \mathrm{~Hz}, \mathrm{H}-3 \mathrm{a}^{\prime}\right), 4.30$ (dd, 1H, $\left.J_{2^{\prime}, 3 \mathrm{~b}^{\prime}} 2.2, J_{3 \mathrm{a}^{\prime}, 3 \mathrm{~b}^{\prime}} 10.4 \mathrm{~Hz}, \mathrm{H}-3 \mathrm{~b}^{\prime}\right)$, 4.11-4.09 (m, 3H, H-5, H-6a, H-6b), 2.55-2.45 (m, 4H, $\mathrm{CH}_{2}-\mathrm{CH}_{2}$ ), 2.14, 2.04, 2.02, $1.98\left(4 \mathrm{~s}, 12 \mathrm{H}, \mathrm{CH}_{3} \mathrm{CO}\right) .{ }^{13} \mathrm{C} \mathrm{NMR}\left(\mathrm{CDCl}_{3}\right): \delta 172.6$, $171.8,171.3,170.5,170.1,169.8(\mathrm{CO}), 145.8(\mathrm{C}-4$ triazole $), 121.3$ (C-5 triazole), 87.5 (C-1'), 78.3 (C-1), 72.5, 72.2 (C-5, C-3'), 70.8 (C-3), $68.3(\mathrm{C}-2), 67.3(\mathrm{C}-4), 65.7\left(\mathrm{C}-2^{\prime}\right), 61.2(\mathrm{C}-6), 35.0\left(\mathrm{CH}_{2} \mathrm{~N}\right)$, 31.2, $30.5\left(\mathrm{CH}_{2}-\mathrm{CH}_{2}\right), 20.7(2 \mathrm{x}), 20.6(2 \mathrm{x})\left(\mathrm{CH}_{3} \mathrm{CO}\right)$. HRMS (ESI): $\mathrm{m} / \mathrm{z} \quad[\mathrm{M}+\mathrm{Na}]^{+}$calcd for $\mathrm{C}_{48} \mathrm{H}_{64} \mathrm{~N}_{10} \mathrm{NaO}_{24}: 1187.3993$, found: 1187.4023 .

\subsubsection{2,2'-bis-\{4-[2,3-di-O-acetyl-N-(2,3,4,6-tetra-O-acetyl- $\beta$-D-galactop} (21)

Compound 21 was obtained by reaction of $\mathbf{5}$ and $\mathbf{1 0}$. Column solvent system: EtOAc: $\mathrm{MeOH}$ (98: 2 to 90: 10), $120 \mathrm{mg}$ (44\%); mp $136-138{ }^{\circ} \mathrm{C} ;[\alpha]_{\mathrm{D}}{ }^{20}+35.7\left(c 0.3, \mathrm{CHCl}_{3}\right) ; R_{\mathrm{f}} 0.13$ (EtAcO: $\mathrm{MeOH}$ 9:1); ${ }^{1} \mathrm{H}$ NMR $\left(\mathrm{CDCl}_{3}\right): \delta 7.83\left(\mathrm{t}, 1 \mathrm{H}, J_{\mathrm{CH} 2, \mathrm{NH}} 5.8 \mathrm{~Hz}, \mathrm{~N} H\right), 7.39$ (s, 1H, H-triazole), $7.10\left(\mathrm{~d}, 1 \mathrm{H}, J_{1, \mathrm{NH}} 9.5 \mathrm{~Hz}, \mathrm{NH}\right), 5.77(\mathrm{~d}, 1 \mathrm{H}$, $\left.J_{\mathrm{CHa}, \mathrm{CHb}} 2.4 \mathrm{~Hz}, \mathrm{CHa}\right), 5.72\left(\mathrm{~d}, 1 \mathrm{H}, J_{\mathrm{CHa}, \mathrm{CHb}} 2.5 \mathrm{~Hz}, \mathrm{CHb}\right), 5.44$ (d, $\left.1 \mathrm{H}, J_{3,4} 3.1 \mathrm{~Hz}, \mathrm{H}-4\right), 5.17$ (dd, $\left.1 \mathrm{H}, J_{3,4} 4.4, J_{2,3} 9.4 \mathrm{~Hz}, \mathrm{H}-3\right), 5.16$ $\left(\mathrm{t}, 1 \mathrm{H}, J_{1,2}=J_{1, \mathrm{NH}} 9.4 \mathrm{~Hz}, \mathrm{H}-1\right), 5.10\left(\mathrm{dd}, 1 \mathrm{H}, J_{1,2} 9.5, J_{2,3} 9.8 \mathrm{~Hz}\right.$, $\mathrm{H}-2), 4.51\left(\mathrm{dd}, 2 \mathrm{H}, J_{\mathrm{CH} 2, \mathrm{NH}} 2.1, J_{\text {gem }} 5.5 \mathrm{~Hz}, \mathrm{CH}_{2} \mathrm{~N}\right), 4.43(\mathrm{~m}, 2 \mathrm{H}$, $\mathrm{CH}_{2} \mathrm{Ar}$ ), 4.11-4.00 (m, 3H, H-5, H-6a, H-6b), 3.77 (t, 2H, J 4.8 Hz, $\left.\mathrm{CH}_{2} \mathrm{O}\right), 2.16,2.14,2.08,2.012(\mathrm{x}), 1.99\left(6 \mathrm{~s}, 18 \mathrm{H}, \mathrm{CH}_{3} \mathrm{CO}\right) .{ }^{13} \mathrm{C}$ NMR $\left(\mathrm{CDCl}_{3}\right): \delta 172.0,170.5,170.1,169.9,169.7,169.5,167.6$, 166.3 (CO), 144.3 (C-4 triazole), 123.8 (C-5 triazole), $78.4(\mathrm{C}-1)$, 72.9 (CHb), 72.4 (C-5), $72.3(\mathrm{CHa}), 70.6(\mathrm{C}-3), 69.2\left(\mathrm{CH}_{2} \mathrm{O}\right), 67.9$ (C-2), $67.2(\mathrm{C}-4), 60.9(\mathrm{C}-6), 50.2\left(\mathrm{CH}_{2} \mathrm{Ar}\right), 35.0\left(\mathrm{CH}_{2} \mathrm{~N}\right), 20.8(3 \mathrm{x})$, 20.7, $20.6(2 \mathrm{x})\left(\mathrm{CH}_{3} \mathrm{CO}\right)$. HRMS (ESI): $m / z[M+\mathrm{Na}]^{+}$calcd for $\mathrm{C}_{54} \mathrm{H}_{72} \mathrm{~N}_{10} \mathrm{NaO}_{31}: 1379.4263$, found: 1379.4243 .
Compounds 11, 14, 17, 19, 21 and 23 were suspended in a mixture of $\mathrm{MeOH}: \mathrm{Et}_{3} \mathrm{~N}: \mathrm{H}_{2} \mathrm{O}$ 4:1:5 (3 mL/0.10 mmol of starting acetylated precursor) and stirred at room temperature. After $1 \mathrm{~h}$, TLC (EtOAc or EtOAc: $\mathrm{MeOH}, 9: 1)$ showed complete consumption of the starting material. The solution was concentrated and the residue was dissolved in water $(1 \mathrm{~mL})$ and passed through a column filled with Dowex MR-3C mixed bed ion-exchange resin. The eluate was concentrated and further purified by filtration through an Octadecyl C18 minicolumn. Evaporation of the solvent afforded the free product, which showed a single spot by TLC (n-BuOH: EtOH: $\left.\mathrm{H}_{2} \mathrm{O}, 1: 1: 1\right)$ whose $\mathrm{R}_{\mathrm{f}}$ are indicated in each case.

\subsubsection{Methyl}

6-deoxy-6-[4-(N'- $\beta$-D-galactopyranosyl-L-tartaramidoyl-N-methyl) 1,2,3-triazol-1-yl]- $\alpha$-D-glucopyranose (12)

Yield: $61 \mathrm{mg}$ (85\%), obtained from $11(120 \mathrm{mg}, 0.127 \mathrm{mmol}) ;[\alpha]_{\mathrm{D}}$ $20+110.9\left(c 0.7, \mathrm{H}_{2} \mathrm{O}\right) ; R_{\mathrm{f}} 0.53 ;{ }^{1} \mathrm{H}$ NMR $\left(\mathrm{D}_{2} \mathrm{O}\right): \delta 7.97(\mathrm{~s}, 1 \mathrm{H}, \mathrm{H}$-triazole), 4.98 (d, 1H, $\left.J_{1,2} 8.8 \mathrm{~Hz}, \mathrm{H}-1\right), 4.84-4.79$ (m, H-6aG, under the signal of HDO), $4.73\left(\mathrm{~d}, 1 \mathrm{H}, J_{1 \mathrm{G}, 2 \mathrm{G}} 3.8 \mathrm{~Hz}, \mathrm{H}-1 \mathrm{G}\right), 4.65(\mathrm{~d}, 1 \mathrm{H}$, $\left.J_{\mathrm{CHa}, \mathrm{CHb}} 1.8 \mathrm{~Hz}, \mathrm{CHa}\right), 4.62\left(\mathrm{~d}, 1 \mathrm{H}, J_{\mathrm{CHa}, \mathrm{CHb}} 2.0 \mathrm{~Hz}, \mathrm{CHb}\right), 4.61(\mathrm{dd}$,

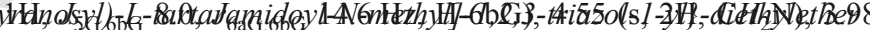
$\left(\mathrm{d}, 1 \mathrm{H}, J_{3,4} 2.1 \mathrm{~Hz}, \mathrm{H}-4\right), 3.92$ (ddd, $1 \mathrm{H}, J_{5 \mathrm{G}, 6 \mathrm{aG}} 2.3, J_{5 \mathrm{G}, 6 \mathrm{bG}} 8.1, J_{4 \mathrm{G}, 5 \mathrm{G}}$ $10.2 \mathrm{~Hz}, \mathrm{H}-5 \mathrm{G}), 3.81$ (t, $\left.1 \mathrm{H}, J_{5,6 \mathrm{a}}=J_{5,6 \mathrm{~b}} 6.2 \mathrm{~Hz}\right), 3.77-3.71(\mathrm{~m}, 4 \mathrm{H}$, H-2, H-3, H-6a, H-6b), 3.65 (t, 1H, $\left.J_{2 \mathrm{G}, 3 \mathrm{G}}=J_{3 \mathrm{G}, 4 \mathrm{G}} 9.5 \mathrm{~Hz}, \mathrm{H}-3 \mathrm{G}\right), 3.53$ $\left(\mathrm{dd}, 1 \mathrm{H}, J_{1 \mathrm{G}, 2 \mathrm{G}} 3.8, J_{2 \mathrm{G}, 3 \mathrm{G}} 9.8 \mathrm{~Hz}, \mathrm{H}-2 \mathrm{G}\right), 3.22\left(\mathrm{dd}, 1 \mathrm{H}, J_{3 \mathrm{G}, 4 \mathrm{G}} 9.2\right.$, $\left.J_{4 \mathrm{G}, 5 \mathrm{G}} 9.9 \mathrm{~Hz}, \mathrm{H}-4 \mathrm{G}\right), 3.12\left(\mathrm{~s}, 3 \mathrm{H}, \mathrm{CH}_{3} \mathrm{O}\right) .{ }^{13} \mathrm{C} \mathrm{NMR}\left(\mathrm{D}_{2} \mathrm{O}\right): \delta 175.3$, $173.5(\mathrm{CO}), 144.6(\mathrm{C}-4$ triazole $), 124.8$ (C-5 triazole), 99.1 (C-1G), 79.7 (C-1), 76.9 (C-5), 73.3 (C-3), 73.0 (C-3G), 72.5 (2x) (CHa, CHb), 71.0 (C-2G), 70.8 (C-4G), 69.9 (C-5G), 69.2 (C-2), 68.7 (C-4), 61.0 (C-6), $54.7\left(-\mathrm{OCH}_{3}\right), 50.9(\mathrm{C}-6 \mathrm{G}), 34.3\left(\mathrm{CH}_{2} \mathrm{~N}\right)$. HRMS (ESI): $\mathrm{m} / \mathrm{z}$ $[M+\mathrm{Na}]^{+}$calcd for $\mathrm{C}_{20} \mathrm{H}_{33} \mathrm{~N}_{5} \mathrm{NaO}_{14}: 590.1922$, found: 590.1948 .

\subsubsection{6,6'-dideoxy-6,6'-bis-[4-(N'- $\beta$-D-galactopyranosyl-L-tartaramidoyl-N-me} (15)

Yield: $43 \mathrm{mg}(87 \%)$ obtained from $14(84 \mathrm{mg}, 0.046 \mathrm{mmol}) ;[\alpha]_{\mathrm{D}}$ ${ }^{20}+112.4\left(c 0.7, \mathrm{H}_{2} \mathrm{O}\right) ; R_{\mathrm{f}} 0.38 ;{ }^{1} \mathrm{H}$ NMR $\left(\mathrm{D}_{2} \mathrm{O}\right) \delta 7.91(\mathrm{~s}, 1 \mathrm{H}, \mathrm{H}-$ triazole), $4.98\left(\mathrm{~d}, 1 \mathrm{H}, J_{1,2} 8.9 \mathrm{~Hz}, \mathrm{H}-1\right), 4.80\left(\mathrm{dd}, 1 \mathrm{H}, J_{5 \mathrm{~T}, 6 \mathrm{aT}} 2.2, J_{6 \mathrm{aT}, 6 \mathrm{bT}}\right.$ $14.5 \mathrm{~Hz}, \mathrm{H}-6 \mathrm{aT}), 4.67$ (d, 1H, $\left.J_{\mathrm{CHa}, \mathrm{CHb}} 1.8 \mathrm{~Hz}, \mathrm{CHa}\right), 4.62$ (d, 1H, $\left.J_{\mathrm{CHa}, \mathrm{CHb}} 1.8 \mathrm{~Hz}, \mathrm{CHb}\right), 4.57\left(\mathrm{dd}, 1 \mathrm{H}, J_{5 \mathrm{~T}, 6 \mathrm{bT}} 8.4, J_{6 \mathrm{aT}, 6 \mathrm{bT}} 14.9 \mathrm{~Hz}\right.$, H-6bT), 4.55 (s, 2H, CH $\left.\mathrm{H}_{2} \mathrm{~N}\right), 4.54\left(\mathrm{~d}, 1 \mathrm{H}, J_{1 \mathrm{~T}, 2 \mathrm{~T}} 4.1 \mathrm{~Hz}, \mathrm{H}-1 \mathrm{~T}\right), 4.01$ (ddd, $1 \mathrm{H}, J_{5 \mathrm{~T}, 6 \mathrm{aT}} 2.3, J_{5 \mathrm{~T}, 6 \mathrm{bT}} 8.4, J_{4 \mathrm{~T}, 5 \mathrm{~T}} 10.3 \mathrm{~Hz}, \mathrm{H}-5 \mathrm{~T}$ ), 4,03 (dd, $\left.1 \mathrm{H}, J_{4,5} 0.7, J_{3,4} 2.9 \mathrm{~Hz}, \mathrm{H}-4\right), 3.81$ (ddd, $1 \mathrm{H}, J_{4,5} 0.7, J_{5,6 \mathrm{a}} 6.0, J_{5,6 \mathrm{~b}}$ 
6.9 Hz, H-5), 3.77-3.72 (m, 5H, H-2, H-3, H-3T, H-6a, H-6b), 3.49 $\left(\mathrm{dd}, 1 \mathrm{H}, J_{1 \mathrm{~T}, 2 \mathrm{~T}} 3.9, J_{2 \mathrm{~T}, 3 \mathrm{~T}}=9.9 \mathrm{~Hz}, \mathrm{H}-2 \mathrm{~T}\right), 3.25\left(\mathrm{dd}, 1 \mathrm{H}, J_{3 \mathrm{~T}, 4 \mathrm{~T}} 9.1\right.$, $\left.J_{4 \mathrm{~T}, 5 \mathrm{~T}} 10.0 \mathrm{~Hz}, \mathrm{H}-4 \mathrm{~T}\right) .{ }^{13} \mathrm{C}$ NMR $\left(\mathrm{D}_{2} \mathrm{O}\right): \delta 175.3,173.5(\mathrm{CO}), 144.7$ (C-4 triazole), 124.7 (C-5 triazole), 93.2 (C-1T), 79.8 (C-1), 76.9 (C-5), 73.3 (C-3), 72.6 (2x) (C-3T, CHa), 72.5 (CHb), 70.9 (C-4T), 70.6, 70.5 (C-2T, C-5T), 69.2 (C-2), 68.7 (C-4), 61.0 (C-6), 50.9 (C-6T), $34.3\left(\mathrm{CH}_{2} \mathrm{~N}\right)$. HRMS (ESI) $\mathrm{m} / \mathrm{z}[\mathrm{M}+\mathrm{H}]^{+}$calcd for $\mathrm{C}_{38} \mathrm{H}_{61} \mathrm{~N}_{10} \mathrm{O}_{27}$ 1089.3702, found 1089.3695. zole), 4.89 (d, 1H, $\left.J_{1,2} 9.0 \mathrm{~Hz}, \mathrm{H}-1\right), 4.51$ (t, 2H, $J_{\mathrm{CH} 2 \mathrm{Ar}, \mathrm{CH} 2 \mathrm{O}} 5.0 \mathrm{~Hz}$, $\left.\mathrm{CH}_{2} \mathrm{Ar}\right), 4.42\left(\mathrm{~s}, 2 \mathrm{H}, \mathrm{CH}_{2} \mathrm{~N}\right), 3.97\left(\mathrm{dd}, 1 \mathrm{H}, J_{4,5} 0.4, J_{3,4} 3.2 \mathrm{~Hz}, \mathrm{H}-4\right)$, 3.87 (t, 2H, $\left.J_{\mathrm{CH} 2 \mathrm{Ar}, \mathrm{CH} 2 \mathrm{O}} 5.0 \mathrm{~Hz}, \mathrm{CH}_{2} \mathrm{O}\right), 3.76$ (ddd, $1 \mathrm{H}, J_{4,5} 0.5, J_{5,6 \mathrm{a}}$ 6.0, $\left.J_{5,6 \mathrm{~b}} 6.5 \mathrm{~Hz}, \mathrm{H}-5\right), 3.71-3.70$ (m, 2H, H-6a, H-6b), 3.70 (dd, $\left.1 \mathrm{H}, J_{3,4} 3.4, J_{2,3} 9.7 \mathrm{~Hz}, \mathrm{H}-3\right), 3.62\left(\mathrm{t}, 1 \mathrm{H}, J_{1,2}=J_{2,3} 9.5 \mathrm{~Hz}, \mathrm{H}-2\right)$, 2.66-2.58 (m, 4H, $\left.\mathrm{CH}_{2}-\mathrm{CH}_{2}\right) .{ }^{13} \mathrm{C} \mathrm{NMR}\left(\mathrm{D}_{2} \mathrm{O}\right): \delta 176.0,174.6$ (CO), 144.5 (C-4 triazole), 123.9 (C-5 triazole), 79.7 (C-1), 76.7 (C-5), 73.3 (C-3), 69.3 (C-2), 68.6, 68.5 ( $\left.\mathrm{CH}_{2} \mathrm{O}, \mathrm{C}-4\right), 60.9$ (C-6), 49.9 $\left(\mathrm{CH}_{2} \mathrm{Ar}\right), 34.5\left(\mathrm{CH}_{2} \mathrm{~N}\right), 30.7,30.3\left(\mathrm{CH}_{2}-\mathrm{CH}_{2}\right)$. HRMS (ESI): $\mathrm{m} / z$

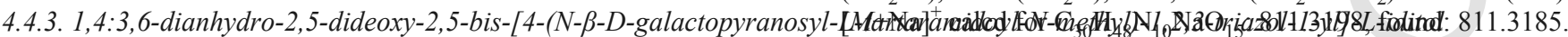
(18)

Yield: $49 \mathrm{mg}(78 \%)$ obtained from $17(96 \mathrm{mg}, 0.07 \mathrm{mmol}) ;[\alpha]_{\mathrm{D}}$ $20+111.3\left(c 0.5, \mathrm{H}_{2} \mathrm{O}\right) ; R_{\mathrm{f}} 0.40 ;{ }^{1} \mathrm{H}$ NMR $\left(\mathrm{D}_{2} \mathrm{O}\right): \delta 7.79(\mathrm{~s}, 1 \mathrm{H}, \mathrm{H}-\mathrm{tri}-$ azole), $5.28\left(\mathrm{dd}, 1 \mathrm{H}, J_{2^{\prime}, 3 \mathrm{~b}^{\prime}} 2.2, J_{2^{\prime}, 3 \mathrm{a}^{\prime}} 5.1 \mathrm{~Hz}, \mathrm{H}-2^{\prime}\right), 5.01$ (s, 1H, H-1'), $4.82\left(\mathrm{~d}, 1 \mathrm{H}, J_{1,2} 8.9 \mathrm{~Hz}, \mathrm{H}-1\right), 4.48\left(\mathrm{~d}, 1 \mathrm{H}, J_{\mathrm{CHa}, \mathrm{CHb}} 2.0 \mathrm{~Hz}, \mathrm{CHa}\right), 4.47$ $\left(\mathrm{d}, 1 \mathrm{H}, J_{\mathrm{CHa}, \mathrm{CHb}} 2.0 \mathrm{~Hz}, \mathrm{CHb}\right), 4.42\left(\mathrm{~d}, 1 \mathrm{H}, J_{\mathrm{gem}} 15.7 \mathrm{~Hz}, \mathrm{CH}_{2} \mathrm{~N}\right), 4.37$ $\left(\mathrm{d}, 1 \mathrm{H}, J_{\text {gem }} 15.7 \mathrm{~Hz}, \mathrm{CH}_{2} \mathrm{~N}\right), 4.29\left(\mathrm{dd}, 1 \mathrm{H}, J_{2^{\prime}, 3 \mathrm{a}^{\prime}} 5.2, J_{3 \mathrm{a}^{\prime}, 3 \mathrm{~b}^{\prime}} 10.9 \mathrm{~Hz}\right.$, H-3a'), 4.21 (dd, $\left.1 \mathrm{H}, J_{2^{\prime}} 3 \mathrm{~b}^{\prime} 2.2, J_{3 \mathrm{a}^{\prime}, 3 \mathrm{~b}^{\prime}} 10.8 \mathrm{~Hz}, \mathrm{H}-3 \mathrm{~b}^{\prime}\right), 3.81$ (dd, $1 \mathrm{H}$, $\left.J_{4,5} 0.7, J_{3,4} 2.8 \mathrm{~Hz}, \mathrm{H}-4\right), 3.59$ (ddd, $1 \mathrm{H}, J_{4,5} 0.6, J_{5,6 \mathrm{a}} 6.2, J_{5,6 \mathrm{~b}} 6.5 \mathrm{~Hz}$, H-5), 3.61-3.56 (m, 4H, H-2, H-3, H-6a, H-6b). ${ }^{13} \mathrm{C}$ NMR $\left(\mathrm{D}_{2} \mathrm{O}\right)$ : $\delta$ 175.3, $173.6(\mathrm{CO}), 144.9$ (C-4 triazole), 123.0 (C-5 triazole), 87.2 (C-1'), 79.7 (C-1), 77.0 (C-5), 73.3, (C-3), 72.5 (2x) (CHa, CHb), 72.1 (C-3'), $69.2(\mathrm{C}-2), 68.7(\mathrm{C}-4), 65.7\left(\mathrm{C}-2^{\prime}\right), 61.0(\mathrm{C}-6), 34.3\left(\mathrm{CH}_{2} \mathrm{~N}\right)$. HRMS (ESI): $m / z[M+\mathrm{H}]^{+}$calcd for $\mathrm{C}_{32} \mathrm{H}_{49} \mathrm{~N}_{10} \mathrm{O}_{20}$ : 893.3119, found: 893.3113 .

4.4.4. 1,4:3,6-dianhydro-2,5-dideoxy-2,5-bis-[4-(N- $\beta$-D-galactopyranosyl-sich (20)

Yield: $150 \mathrm{mg}(86 \%)$ obtained from $19(245 \mathrm{mg}, 0.21 \mathrm{mmol}) ;[\alpha]_{\mathrm{D}}$ $20+46.9\left(c 0.9, \mathrm{H}_{2} \mathrm{O}\right) ; R_{\mathrm{f}} 0.47 ;{ }^{1} \mathrm{H}$ NMR $\left(\mathrm{D}_{2} \mathrm{O}\right): \delta 7.78(\mathrm{~s}, 1 \mathrm{H}, \mathrm{H}$-triazole), $5.28\left(\mathrm{dd}, 1 \mathrm{H}, J_{2^{\prime} 3 \mathrm{~b}^{\prime}} 1.9, J_{2^{\prime}, 3 \mathrm{a}^{\prime}} 5.1 \mathrm{~Hz}, \mathrm{H}-2^{\prime}\right), 5.04(\mathrm{~s}, 1 \mathrm{H}$, H-1'), 4.74 (d, 1H, $\left.J_{1,2} 9.0 \mathrm{~Hz}, \mathrm{H}-1\right), 4.33-4.26$ (m, 3H, H-3a', $\mathrm{CH}_{2} \mathrm{~N}$ ), 4.24 (dd, $\left.1 \mathrm{H}, J_{2^{\prime}, 3 \mathrm{~b}^{\prime}} 1.9, J_{3 \mathrm{a}^{\prime}, 3 \mathrm{~b}^{\prime}} 10.8 \mathrm{~Hz}, \mathrm{H}-3 \mathrm{~b}^{\prime}\right), 3.81$ (dd, $1 \mathrm{H}, J_{4,5}$ $\left.0.6, J_{3,4} 3.3 \mathrm{~Hz}, \mathrm{H}-4\right), 3.59$ (ddd, $1 \mathrm{H}, J_{4,5} 0.8, J_{5,6 \mathrm{a}} 6.0, J_{5,6 \mathrm{~b}} 6.8 \mathrm{~Hz}$, H-5), 3.58-3.52 (m, 3H, H-3, H-6a, H-6b), 3.46 (t, $1 \mathrm{H}, J_{1,2}=J_{2,3}$ $9.6 \mathrm{~Hz}, \mathrm{H}-2), 2.53-2.40\left(\mathrm{~m}, 4 \mathrm{H}, \mathrm{CH}_{2}-\mathrm{CH}_{2}\right) .{ }^{13} \mathrm{C} \mathrm{NMR}\left(\mathrm{D}_{2} \mathrm{O}\right): \delta$ 176.0, $174.8(\mathrm{CO}), 145.1$ (C-4 triazole), 123.0 (C-5 triazole), 87.2 (C-1'), 79.7 (C-1), 76.7 (C-5), 73.3, (C-3), 72.1 (C-3'), 69.3 (C-2), 68.6 (C-4), $65.7\left(\mathrm{C}-2^{\prime}\right), 60.9(\mathrm{C}-6), 34.5\left(\mathrm{CH}_{2} \mathrm{~N}\right), 30.7,30.3\left(\mathrm{CH}_{2}-\mathrm{CH}_{2}\right)$. HRMS (ESI): $m / z[M+\mathrm{H}]^{+}$calcd for $\mathrm{C}_{32} \mathrm{H}_{49} \mathrm{~N}_{10} \mathrm{O}_{16}: 829.3323$, found: 829.3348 .

4.4.5. 2,2'-bis-[4-(N- $\beta$-D-galactopyranosyl-L-tartaramidoyl-N-methyl)-1,2 diethylether (22)

Yield: $25 \mathrm{mg}$ (73\%) obtained from 21 (50 mg, 0.04); $[\alpha]_{\mathrm{D}}{ }^{20}+73.0$ (c $\left.1.1, \mathrm{H}_{2} \mathrm{O}\right) ; R_{\mathrm{f}} 0.41 ;{ }^{1} \mathrm{H}$ NMR $\left(\mathrm{D}_{2} \mathrm{O}\right): \delta 7.73$ (s, $1 \mathrm{H}, \mathrm{H}$-triazole), $4.97\left(\mathrm{~d}, 1 \mathrm{H}, J_{1,2} 8.5 \mathrm{~Hz}, \mathrm{H}-1\right), 4.66\left(\mathrm{~d}, 1 \mathrm{H}, J_{\mathrm{CHa}, \mathrm{CHb}} 1.8 \mathrm{~Hz}, \mathrm{CHa}\right)$, $4.64\left(\mathrm{~d}, 1 \mathrm{H}, J_{\mathrm{CHa}, \mathrm{CHb}} 1.7 \mathrm{~Hz}, \mathrm{CHb}\right), 4.54\left(\mathrm{~s}, 2 \mathrm{H}, \mathrm{CH}_{2} \mathrm{~N}\right), 4.51(\mathrm{t}, 2 \mathrm{H}$, $\left.J_{\mathrm{CH} 2 \mathrm{Ar}, \mathrm{CH} 2 \mathrm{O}} 4.9 \mathrm{~Hz}, \mathrm{CH}_{2} \mathrm{Ar}\right), 3.98$ (d, $\left.1 \mathrm{H}, J_{3,4} 2.0 \mathrm{~Hz}, \mathrm{H}-4\right), 3.87$ (t, $\left.2 \mathrm{H}, J_{\mathrm{CH} 2 \mathrm{Ar}, \mathrm{CH} 2 \mathrm{O}} 4.9 \mathrm{~Hz}, \mathrm{CH}_{2} \mathrm{O}\right), 3.81\left(\mathrm{t}, 1 \mathrm{H}, J_{5,6 \mathrm{a}}=J_{5,6 \mathrm{~b}} 6.0 \mathrm{~Hz}, \mathrm{H}-5\right)$, 3.75-3.72 (m, 4H, H-2, H-3, H-6a, H-6b). ${ }^{13} \mathrm{C}$ NMR $\left(\mathrm{D}_{2} \mathrm{O}\right): \delta 175.3$, 173.6 (CO), 144.3 (C-4 triazole), 124.0 (C-5 triazole), 79.7 (C-1), 76.9 (C-5), 73.3 (C-3), 72.5 (2x) (CHa, CHb), 69.2 (C-2), 68.7 (C-4), 68.5 $\left(\mathrm{CH}_{2} \mathrm{O}\right), 61.0(\mathrm{C}-6), 49.9\left(\mathrm{CH}_{2} \mathrm{Ar}\right), 34.3\left(\mathrm{CH}_{2} \mathrm{~N}\right)$. HRMS (ESI): $\mathrm{m} / z$ $[M+\mathrm{Na}]^{+}$calcd for $\mathrm{C}_{30} \mathrm{H}_{48} \mathrm{~N}_{10} \mathrm{NaO}_{19}$ : 875.2995, found: 875.2965.

4.4.6. 2,2'-bis-4-[(N- $\beta$-D-galactopyranosyl-succinammoyl- $N$-methyl $)-1,2,3$ (24)

Yield: $62 \mathrm{mg}(76 \%)$, obtained from $23(116 \mathrm{mg}, 0.10 \mathrm{mmol}) ;[\alpha]_{\mathrm{D}}$ ${ }^{20}+7.5\left(c 1.0, \mathrm{H}_{2} \mathrm{O}\right) ; R_{\mathrm{f}} 0.36 ;{ }^{1} \mathrm{H}$ NMR $\left(\mathrm{D}_{2} \mathrm{O}\right): \delta 7.71(\mathrm{~s}, 1 \mathrm{H}, \mathrm{H}$-tria-

\subsection{Enzyme linked lectin assay (ELLA)}

Nunc-Inmuno ${ }^{\mathrm{TM}}$ plates (MaxiSorp ${ }^{\mathrm{TM}}$ ) were coated overnight with click lactose-polystyrene glycopolymer [44] at $100 \mu \mathrm{L} /$ well diluted from a stock solution of $10 \mu \mathrm{g} \mathrm{mL}^{-1}$ in $0.01 \mathrm{~m}$ phosphate buffer saline (PBS, pH 7.3 containing $0.1 \mathrm{~mm} \mathrm{Ca}^{2+}$ and $0.1 \mathrm{~mm} \mathrm{Mn}^{2+}$ ) at room temperature. The wells were then washed three times with $300 \mu \mathrm{L}$ of washing buffer (containing $0.05 \%$ (v/v) Tween 20) (PBST). The washing procedure was repeated after each of the incubations throughout the assay. The wells were then blocked with $150 \mu \mathrm{L} /$ well of $1 \%$ BSA/PBS for $1 \mathrm{~h}$ at $37^{\circ} \mathrm{C}$. After washing, the wells were filled with $100 \mu \mathrm{L}$ of serial dilutions of horseradish peroxidase labeled peanut (Arachis hypogaea) lectin (PNA-HRP) from $10^{-1}$ to $10^{-5} \mathrm{mg} \mathrm{mL}^{-1}$ in PBS, and incubated at $37^{\circ} \mathrm{C}$ for $1 \mathrm{~h}$. The plates were washed and 50

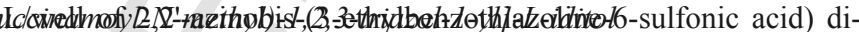
ammonium salt (ABTS) $\left(0.25 \mathrm{mg} \mathrm{mL}^{-1}\right)$ in citrate buffer $(0.2 \mathrm{~m}, \mathrm{pH}$ 4.0 with $0.015 \% \mathrm{H}_{2} \mathrm{O}_{2}$ ) was added. The reaction was stopped after $20 \mathrm{~min}$ by adding $50 \mu \mathrm{L} /$ well of $1 \mathrm{~m} \mathrm{H}_{2} \mathrm{SO}_{4}$ and the absorbances were measured at $415 \mathrm{~nm}$. Blank wells contained citrate-phosphate buffer. The concentration of lectin-enzyme conjugate that displayed an absorbance between 0.8 and 1.0 was used for inhibition experiments. ELLA is considered to provide information on the intrinsic multivalent effect, devoid of aggregation phenomena, since the presence of the voluminous HRP enzyme prevents cross-linking the lectin unless very long spacer arms are incorporated in the divalent ligand [12,23].

In order to carry out the inhibition experiments, each inhibitor was added in a serial of 2-fold dilutions $(60 \mu \mathrm{L} /$ well $)$ in PBS with $60 \mu \mathrm{L}$ of the desired PNA-peroxidase conjugate concentration on Nunclon ${ }^{\mathrm{TM}}$ (Delta) microtiter plates and incubated for $1 \mathrm{~h}$ at $37^{\circ} \mathrm{C}$. The above solutions $(100 \mu \mathrm{L})$ were then transferred to the lactose polymer-coated Mitcrioglates-y $y$ hy hich were incubated for $1 \mathrm{~h}$ at $37^{\circ} \mathrm{C}$. The plates were washed and the ABTS substrate was added (50 $\mu \mathrm{L} /$ well). Color development was stopped after $20 \mathrm{~min}$ and the absorbances were measured. The percent of inhibition was calculated as follows: \% Inhibition $=\left(A_{\text {(no inhibitor) }}-A_{\text {(with inhibitor) }}\right) / A_{\text {(no inhibitor) }} \times 100$. The $\mathrm{IC}_{50}$ values corresponding to lactose and galactose were determined in the same conditions. A positive control of a high affinity multivalent lactosylated cyclodextrin (valency: 21) ligand was also tested to validate the methodology. The $\mathrm{IC}_{50}$ value obtained for this ligand was $25 \pm 2 \mu \mathrm{M}$ (Lit.: $21 \pm 2 \mu \mathrm{M}$ ) [40].

Results in triplicate were used for plotting the inhibition curves for each individual ELLA experiment. Typically, the $\mathrm{IC}_{50}$ values (concentration required for $50 \%$ inhibition of the Con A-coating lactose polymer association) obtained from several independently performed tests

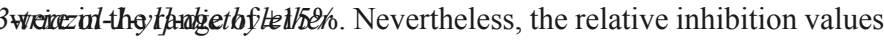
calculated from independent series of data were highly reproducible. 


\subsection{Docking and molecular dynamics calculations}

Dockign and Molecular Dynamics (MD) calculations were performed as in previous works [41] using modified AUTODOCK [30] version for carbohydrates and AMBER MD package (Ref amber). Briefly, minimized structures of lactose, and compounds $\mathbf{A}$ and $\mathbf{B}$ (represented in Fig. S1), were docked into the carbohydrate-binding site of the PNA lectin (PDBid 1CR7) using previously reported parameters. The available X-ray PNA-Lactose structure was used as a positive control. For MD simulations Amberff99SB force field was used for the protein and Glycam-04 plus GAFF (Refs Glycam y Gaff) for the ligands. Production simulations were run for $100 \mathrm{~ns}$ and analyzed with VMD 1.8.7 program (Figs. 2a and S2b, Figs. S3a and S3b).

\section{Acknowledgements}

Support for this work from the National Agency for Promotion of Science and Technology, ANPCyT, Project PICT Bicentenario 2010 No. 1080, the National Research Council CONICET, the University of Buenos Aires (UBACyT 2013-2016 GC, 20020120100101BA), Argentina, the Centre National de la Recherche Scientifique (CNRS), France, the Spanish MINECO (SAF2016-76083-R and CTQ2015-64425-C2-1-R), the Junta de Andalucía (FQM-1467) and the European Regional and Social Founds (FEDER and FSE) is gratefully acknowledged. We deeply thank to Dr. Lautaro Álvarez for his kind help with the modelling experiments, Dr. David Lesur for conducting some of the HMRS-ESI determinations and Aurélie Vallin for technical assistance. MEC is a fellow from CONICET. MLU and OV are research members of CONICET.

\section{Appendix A. Supplementary data}

Supplementary data related to this article can be found at http://dx. doi.org/10.1016/j.carres.2017.03.018.

\section{References}

[1] (a) A. Varki, R.D. Cummings, J.D. Esko, H.H. Freeze, P. Stanley, C.R Bertozzi, G.W. Hart, M.E. Etzler (Eds.), Essentials of Glycobiology, 2nd Ed., Cold Spring Harbor Laboratory Press, New York, 2009-1999;

(b) Y.C. Lee, R.T. Lee, Acc. Chem. Res. 28 (1995) 321-327;

(c) H.-J. Gabius (Ed.), The Sugar Code, Fundamentals of Glycosciences, Wiley-Blackwell;

(d) J.L. Jiménez Blanco, C. Ortiz Mellet, J.M. García Fernández, Chem. Soc. Rev. 42 (2013) 4518-4531.

[2] M.C. Fernández-Alonso, D. Díaz, M.A. Berbis, F. Marcelo, J. Cañada, J. Jiménez-Barbero, Curr. Prot. Pept. Sci. 13 (2012) 816-830.

[3] J.J. Asensio, A. Ardá, F.J. Cañada, J. Jiménez-Barbero, Acc. Chem. Res. 46 (2013) 946-954.

[4] V. Sharma, V.R. Srinivas, P. Adhikari, M. Vijayan, A. Surolia, Glycobiology 8 (1998) 1007-1012.

[5] O. Srinivas, N. Mitra, A. Surolia, N. Jayaraman, Glycobiology 15 (2005) 861-873.

[6] (a) M.J. Swamy, D. Gupta, S.K. Mahanta, A. Surohat, Carbohydr. Res. 213 (1991) 59-67;

(b) R. Lotan, E. Skutelsky, D. Danon, N. Sharon, J. Biol. Chem. 250 (1975) 8518-8523;

(c) V. Sharma, M. Vijayan, V. Surolia, J. Biol. Chem. 271 (1996) 21209-21213; (d) R. Ravishankar, M. Ravindran, K. Suguna, A. Surolia, M. Vijayan, Curr. Sci. 72 (1997) 855-861.

[7] A.J. Cagnoni, J. Kovensky, M.L. Uhrig, J. Org. Chem. 79 (2014) 6456-6467.

[8] A.J. Cagnoni, O. Varela, J. Kovensky, M.L. Uhrig, Eur. J. Org. Chem. (2013) 972-983.

[9] A.J. Cagnoni, O. Varela, J. Kovensky, M.L. Uhrig, Org. Biomol. Chem. 11 (2013) 5500-5511.
[10] R. Ravishankar, V. Thomas, V. Suguna, V. Surolia, V. Vijayan, Proteins 43 (2001) 260-270.

[11] E.V. Chandrasekaran, J. Xue, J. Xia, S.D. Khaja, C.F. Piskorz, R.D. Locke, S. Neelamegham, K.L. Matta, Glycoconj. J. 33 (2016) 819-836.

[12] R. Banerjee, K. Das, R. Ravishankar, K. Suguna, A. Surolia, M. Vijayan, J. Mol. Biol. 259 (1996) 281-296.

[13] V.V. Mossine, V.V. Glinsky, T.P. Mawhinney, in: Galectins, A.A. Klyosov, Z.J. Witczak, D. Platt (Eds.), Food-related Carbohydrate Ligands for Galectins, John Wiley and Sons, Hoboken, New Jersey, 2008, pp. 235-270.

[14] H. Ideo, A. Seko, T. Ohkura, K.L. Matta, K. Yamashita, Glycobiology 12 (2002) 199-208.

[15] N. D'Amelio, C. Esteban, A. Coslovi, L. Feruglio, F. Uggeri, M. Villegas, J. Benegas, S. Paoletti, I. Donati, J. Phys. Chem. B 117 (2013) 13578-13587.

[16] M. Avalos, R. Babiano, M.J. Carretero, P. Cintas, F.J. Higes, J.L. Jiménez, J.C. Palacios, Tetrahedron 54 (1998) 615-628

[17] R. Masaka, M. Ogata, Y. Misawa, M. Yano, C. Hashimoto, T. Murata, H. Kawagishi, T. Usui, Bioorg. Med. Chem. 18 (2010) 621-629.

[18] I. Vrasidas, S. André, P. Valentini, C. Böck, M. Lensch, H. Kaltner, R.M.J. Liskamp, H.J. Gabius, R. Pieters, J. Org. Biomol. Chem. 1 (2003) 803-810.

[19] I. Baussanne, J.M. Benito, C. Ortiz Mellet, J.M. García Fernández, J. Defaye, ChemBioChem 2 (2001) 777-783.

[20] S. André, D.V. Jarikote, D. Yan, L. Vincenz, G.-N. Wang, H. Kaltner, P.V. Murphy, H.J. Gabius, Bioorg. Med. Chem. Lett. 22 (2012) 313-318.

[21] (a) J.F. Espinosa, F.J. Cañada, J.L. Asensio, M. Martín-Pastor, H. Dietrich, M. Martín-Lomas, R.R. Schmidt, J. Jiménez-Barbero, J. Am. Chem. Soc. 118 (1996) 10862-10871; (b) R. Ravishankar, A. Surolia, M. Vijayan, S. Lim, Y. Kishi, J. Am. Chem. Soc. 120 (1998) 11297-11303;

(c) J.F. Espinosa, M. Bruix, O. Jarreton, T. Skrydstrup, J.M. Beau, J. Jiménez-Barbero, Chem. Eur. J. 5 (1999) 442-448;

(d) J. Jiménez-Barbero, J.F. Espinosa, J.L. Asensio, F.J. Cañada, A. Poveda, Adv. Carbohydr. Chem. Biochem. 56 (2000) 235-284;

(e) A. García-Herrero, E. Montero, J.L. Muñoz, J.F. Espinosa, A. Vián, J.L. García, J.L. Asensio, F.J. Cañada, J. Jiménez-Barbero, J. Am. Chem. Soc. 124 (2002) 4804-4810.

[22] M. Almant, A. Mastouri, V. Gallego-Yerga, J.M. García Fernandez, C. Ortiz Mellet, J. Kovensky, S. Morandat, K. El Kirat, S.G. Gouin, Chem. Eur. J. 19 (2013) 729-738.

[23] J.I. Lundquist, E. Toone, J. Chem. Rev. 102 (2002) 555-578.

[24] Y.M. Chabre, R. Roy, Adv. Carbohydr. Chem. Biochem. 63 (2010) 165-393.

[25] M. Gingras, Y.M. Chabre, M. Roy, R. Roy, Chem. Soc. Rev. 42 (2013) $4823-4841$

[26] S. Bhatia, M. Dimde, R. Haag, Med. Chem. Commun. 5 (2014) 862-878.

[27] S. Cecioni, J.P. Praly, S.E. Matthews, M. Wimmerov, A. Imberty, S. Vidal, Chem. Eur. J. 18 (2012) 6250-6263.

[28] (a) F. Sansone, A. Casnati, Chem. Soc. Rev. 42 (2013) 4623-4639; (b) A. Martínez, C. Ortiz Mellet, J.M. García Fernández, Chem. Soc. Rev. 42 (2013) 4746-4773;

(c) Y.M. Chabre, R. Roy, Chem. Soc. Rev. 42 (2013) 4657-4708.

[29] C.H. Zhou, Y. Wang, Curr. Med. Chem. 19 (2012) 239-280.

[30] G.M. Morris, D.S. Goodsell, R.S. Halliday, R. Huey, W.E. Hart, R.K. Belew, A.J. Olson, J. Comput. Chem. 19 (1998) 1639-1662.

[31] F.D. Tropper, F.O. Andersson, S. Braun, R. Roy, Synthesis (1992) 618-620.

[32] (a) C. Ortiz Mellet, A. Méndez-Ardoy, J.M. García Fernández, Click multivalent glycomaterials: glycoclusters, glycopolymers, hybrid glycomaterials and glycosurfaces, in: Z.J. Witczak, R. Bielski (Eds.), Click Chemistry in Glycoscience: New Developments and Strategies, Wiley, New Jersey, 2013, pp. 143-182;

(b) M.L. Uhrig, J. Kovensky, Clicking sugars onto sugars: oligosaccharide analogues and glycoclusters on carbohydrate scaffolds, in: Z.J. Witczak, R. Bielski (Eds.), Click Chemistry in Glycoscience: New Developments and Strategies, Wiley, New Jersey, 2013, pp. 107-142.

[33] M.E. Cano, R. Agusti, A.J. Cagnoni, M.F. Tesoriero, J. Kovensky, M.L. Uhrig, R.M. Lederkremer, Beilstein J. Org. Chem. 10 (2014) 3073-3086.

[34] S.G. Gouin, E. Vanquelef, J.M. García Fernandez, C. Ortíz Mellet, F.-Y. Dupradeau, J. Kovensky, J. Org. Chem. 72 (2007) 9032-9045.

[35] S.G. Gouin, A. Wellens, J. Bouckaert, J. Kovensky, ChemMedChem 4 (2009) 749-755.

[36] M. Köhn, J.M. Benito, C. Ortíz Mellet, T.K. Lindhorst, J.M. García Fernández, ChemBioChem 5 (2004) 771-777.

[37] A.J. Cagnoni, O. Varela, S.G. Gouin, J. Kovensky, M.L. Uhrig, J. Org. Chem. 76 (2011) 3064-3077.

[38] C. Besset, J.P. Pascault, E. Fleury, E. Drockenmuller, J. Bernard, Biomacromolecules 11 (2010) 2797-2803.

[39] J. Rodríguez-Lavado, M. de La Mata, J.L. Jiménez-Blanco, M.I. García-Moreno, J.M. Benito, A. Díaz-Quintana, J.A. Sánchez-Alcázar, K. Higaki, E. Nanba, K. Ohno, Y. Suzuki, C. Ortiz Mellet, J.M. García Fernández, Org. Biomol. Chem. 12 (2014) 2289-2301.

[40] M. Gómez García, J.M. Benito, A.P. Butera, C. Ortiz Mellet, J.M. García Fernández, J.L. Jiménez Blanco, J. Org. Chem. 77 (2012) 1273-1288. 
[41] (a) D.F. Gauto, S. Di Lella, D.A. Estrin, H.L. Monaco, M.A. Martí, Carbohydr. Res. 346 (2011) 939-948;

(b) D.F. Gauto, A.A. Petruk, C.P. Modenutti, J.I. Blanco, S. Di Lella, M.A. Martí, Glycobiology 23 (2013) 241-258;

(c) C.P. Modenutti, D.F. Gauto, L. Radusky, J.I. Blanco, A. Turjanski, S. Hajos, M.A. Marti, Glycobiology 25 (2015) 181-196.

[42] V. Wittmann, R.J. Pieters, Chem. Soc. Rev. 42 (2013) 4492-4503.
[43] R.L. Shriner, C.L. Furrow, N.J. Leonard, R.R. Sauers, Org. Synth. 35 (1955) 49

[44] M. Ortega-Muñoz, J. Morales-Sanfrutos, F. Perez-Balderas, F. Hernández-Mateo, M.D. Girón-González, N. Sevillano-Tripero, R. Salto-González, F. Santoyo-González, Org. Biomol. Chem. 5 (2007) 2291-2301. 